\title{
Antitestmediált rejekció: kihívás a veseátültetett betegek kezelésében
}

\author{
Nemes Balázs dr. ${ }^{1}$ - P. Szabó Réka dr. ${ }^{1}$ - Bidiga László dr. ${ }^{2}$ \\ Kalmár Nagy Károly dr. ${ }^{3}$ - Illésy Lóránt dr. ${ }^{1}$ - Szilvási Anikó dr. ${ }^{4}$ \\ Debreceni Egyetem, Általános Orvostudományi Kar, 'Sebészeti Intézet, Szervtranszplantációs Tanszék, \\ ${ }^{2}$ Patológiai Intézet, Debrecen \\ ${ }^{3}$ Pécsi Egyetem, Általános Orvostudományi Kar, Sebészeti Klinika, Pécs \\ ${ }^{4}$ Országos Vérellátó Szolgálat, Transzplantációs Immungenetikai Laboratórium, Budapest
}

\begin{abstract}
A veseátültetés utáni hosszú távú túlélést befolyásoló tényezők egyike az antitestmediált rejekció (ABMR). A szerzők áttekintést nyújtanak az ABMR jelenleg ismert diagnosztikai és kezelési hátteréről. A Debreceni és a Pécsi Egyetem transzplantációs központjainak együttmúködése alapján áttekintik a 2013 és 2017 közötti időszakban végzett veseátültetések után kialakult korai ABMR-eseteket és a releváns közleményeket. A két központban összesen 454 veseátültetés történt. ABMR-diagnózist összesen 18 esetben állítottunk fel (4\%). Minden esetben perkután biopszia történt. A betegek közül 22\% volt primer, 78\% retranszplantált eset. Az átlagéletkor 51,2 06 év volt. A veseátültetés után az ABMR diagnózisáig eltelt idő $15,4 \pm 22,1$ hónap volt. A C4d-pozitivitást 7 esetben sikerült igazolni, ami az összes ABMR-eset 39\%-a. Összesen 16 betegnél történt szteroidbolus + intravénás immunglobulin (IVIG) + plazmaferézis (PF) kezelés, a 6 debreceni beteg közül 5 kapott ezenfelül rituximabot és 1 alemtuzumabot. $9(47,4 \%)$ beteg él működő beültetett vesével, 4 beteg meghalt $(21 \%)$, és 5 került vissza múvesekezelésre graftvesztés miatt $(31 \%)$. Az ABMR veszélyes szövődmény a veseátültetés után. A diagnosztikus kritériumok sokáig változtak. A gold standard a szövettan. A C4d-esetekben is lehet akcelerált ABMR. A retranszplantáción átesett fiatalabb, preformált donorspecifikus antitesttel (DSA) jelentkező betegek és azok, akik EC-donorból kapnak vesét, kockázati csoportot jelentenek. A de novo DSA megjelenése, az átlagos fluoreszcenciaintenzitás (MFI) kinetikája lehet az a pont, amely felhívja a figyelmet az akut ABMR veszélyére. A rituximab hatékonyságát megkérdőjelezik, az új gyógyszerekkel (belatacept, bortezomib vagy ekulizumab) még nincs elég tapasztalat, vagy rendkívül drágák. Saját anyagunkban a $40 \%$ feletti gyógyulási arány kiemelkedően jó eredmény.
\end{abstract}

Orv Hetil. 2018; 159(46): 1913-1929.

Kulcsszavak: veseátültetés, rejekció, antitest, plazmaferézis, rituximab

\section{Antibody-mediated rejection: challenge of the treatment in kidney transplantated patients}

Antibody-mediated rejection (ABMR) is one of the factors affecting the long-term graft survival after kidney transplantation (KT). Two kidney transplant centres (University of Debrecen and University of Pécs) followed up their data of cadaveric KTs that had been performed between 2013 and 2017, and reviewed the literature. There were 454 KTs in the mentioned period, 18 cases (4\%) were recognised as ABMRs. Biopsy has been performed in all cases. $22 \%$ were primary, and $78 \%$ retransplanted patients. The average age was $51.2 \pm 6$ years. ABMR occurred $15.4 \pm 22.1$ months after KT. Histology showed C4d positivity in 39\% of the cases. The treatment was steroid bolus + intravenous immunoglobulin (IVIG) + plasma exchange (PE) in 16 cases, rituximab was additionally given in 5 cases. $47.4 \%$ of the patients are alive with a functioning graft, four $(21 \%)$ died, and $31 \%$ of the patients had a graft loss due to ABMR. ABMR is a dangerous complication after KT. Diagnostic criteria has been unclear for years. Gold standard is the histology, however, accelerated ABMR may occur even in C4d negative cases. The exposed group includes young, retransplanted patients, having a preformed donor-specific antibody (DSA), and receiving a graft from an EC donor. The occurrence of de novo DSA and the kinetics of mean fluorescence intensity (MFI) of existing ones can be a signal for the risk of an ABMR. The effectiveness of rituximab is not proven, there is a lack of long-term controlled trials for new drugs. Our results of over $40 \%$ recovery is an extensively good result. 
Keywords: kidney transplant, rejection, antibody, plasmapheresis, rituximab

Nemes B, P Szabó R, Bidiga L, Kalmár Nagy K, Illésy L, Szilvási A. [Antibody-mediated rejection: challenge of the treatment in kidney transplantated patients]. Orv Hetil. 2018; 159(46): 1913-1929.

(Beérkezett: 2018. szeptember 6.; elfogadva: 2018. szeptember 22.)

\section{Rövidítések}

$\mathrm{AB} 0$ = AB0 fó vércsoport; $\mathrm{AB} 0 \mathrm{i}=\mathrm{AB} 0$-inkompatibilis; $\mathrm{ABMR}$ $=($ antibody-mediated rejection $)$ antitestmediált rejekció; $\mathrm{AM}=$ (acceptable mismatch) elfogadható (immunológiai) eltérés; $\mathrm{AMR}=$ antitestmediált rejekció $; \mathrm{APC}=($ antigen-presenting cell) antigénprezentáló sejt; ATIR = (angiotensin II type 1 receptor) angiotenzin-II-receptor-1; ATG = antithymocitaglobulin; $\mathrm{CAN}=$ (chronic allograft nephropathy) krónikus allograftnephropathia; $\mathrm{CDC}=$ (complement-dependent cytotoxicity) komplementdependens citotoxicitás; CI = (confidence interval) konfidenciaintervallum; CIT $=($ cold ischemic time) hidegischaemiás időtartam; $\mathrm{CMV}=$ cytomegalovirus; $\mathrm{CNI}=$ (calcineurin inhibitor $)$ kalcineurininhibitor; $\mathrm{DM}=$ dia betes mellitus; DSA = donorspecifikus antitest DSAST $=$ DSAspecifikus transzkripciós szett; EC-donor $=$ extended criteria donor (nem ideális paraméterekkel rendelkező kadáver donor); ELISA = enzyme-linked immunosorbent assay) enzimhez kapcsolt immunszorbensvizsgálat; ELISPOT = enzyme-linked immunosorbent spot; EM = elektronmikroszkópia; ENCKEP = (European Network for Collaboration on Kidney Exchange Programmes) Európai Élődonor Vesecsere Programok Együttmúködési Hálózata; ESZK TTT = Egészségügyi Szakmai Kollégium, Transzplantációs Tagozati Tanács; ET = Eurotransplant; $\mathrm{ETAR}=$ (endothelin type $\mathrm{A}$ receptor $)$ endothelin A-receptor; ETKAS = (Eurotransplant Kidney Allocation System) Európai Veseallokációs Rendszer; GFR = glomerulusfiltrációs ráta; GPCR $=($ G-protein coupled receptor $)$ G-proteinkapcsolt receptor; GZMB = granzim $\mathrm{B} ; \mathrm{HBV}=$ hepatitis B-vírus; HCV = hepatitis C-vírus; HIV = humán immundeficientiavírus; HLA = humán leukocytaantigén; HLAi = HLA-inkompatibilis; HLA-tipizálás = HLA-típusok azonosítása a sejtfelszínen kimutatható antigének azonosításával (szerológiai módszer) vagy génszintű vizsgálattal (molekuláris módszer), az utóbbi technika segítségével allélszintű meghatározás válik lehetővé; a szövet- és szervátültetéshez vizsgált locusok: HLA-A, HLA-B, HLA-C, HLA-DR és HLA-DQ; HR = (hazard ratio) kockázati arány; IA = immunadszorpció; IF = interstitialis fibrosis; IFN $\gamma=$ interferon-gamma; Ig = immunglobulin; IP = immunperoxidáz; IVIG = intravénás immunglobulin; kSORT = Kidney Solid Organ Response Test; LAM = lymphangioleiomyomatosis; LRLT = (living related liver transplantation $)$ élódonor májátültetés; Luminex-SAB = Luminex single antigen bead; $\mathrm{MFI}=$ (mean fluorescence intensity) átlagos fluoreszcenciaintenzitás; $\mathrm{MHC}=$ (major histocompatibility complex) fó hisztokompatibilitási komplex; MIC $=$ MHC Class I-related chain; mikro-RNS $=$ mikroribonukleinsav; $\mathrm{mRNS}=($ messenger RNS) hírvivő RNS; mTOR = mammalian target of rapamycin $; \mathrm{MVI}=$ microvascularis gyulladás $; \mathrm{NGAL}=$ neutrophil zselatináz asszociálta lipokalin; NK-sejt $=$ (natural killer) természetes ölősejt; OVSZ = Országos Vérellátó Szolgálat; $\mathrm{PCR}=$ (polymerase chain reaction) polimeráz-láncreakció; PE $=($ plasma exchange $)$ plazmacsere $; \mathrm{PF}=$ plazmaferézis $; \mathrm{PRA}=$ (panel reactive antibody) panelreaktív antitest: százalékos arányban mutatja, milyen arányban hordoz HLA-ellenes antitestet a vizsgált személy; a kimutatás során ismert HLA antigéneket hordozó panelszemélyek lymphocytával reagáltatják a beteg savóját; PRF = perforin; PTC = peritubularis kapilláris; $\mathrm{rMAB}=$ rituximab; $\mathrm{RR}=$ (relative risk) viszonylagos kockázat; $\mathrm{RTPCR}=($ reverse transcriptase polymerase chain reaction $)$ reverz transzkriptáz polimeráz-láncreakció; RT-PCR = (real-time polymerase chain reaction) valós idejű polimeráz-láncreakció; $\mathrm{SAB}=$ single antigen bead; $\mathrm{SRE}=($ systemic lupus erythematosus) szisztémás lupus erythematosus; TGP $=$ (transplant glomerulopathy) transzplantációs glomerulopathia; TMA = thromboticus microangiopathia; $\mathrm{TN}=$ tubularis necrosis; $\mathrm{VB}=$ ventrobasalis

A veseátültetés hazánkban is a végstádiumú veseelégtelenség rutinszerü kezelésévé vált. A modern immunszuppresszív gyógyszerek, multidiszciplináris posztoperatív betegellátás mellett, a transzplantáció utáni korai szövődmények aránya minimális, a figyelem középpontjába a hosszú távú túlélést befolyásoló tényezők léptek [1]. A veseátültetés eredményességét több tényezővel lehet mérni. Ilyen a beteg- és grafttúlélés, azaz a beültetett vese elvesztésének relatív és abszolút kockázata. A vesegrafttúlélést befolyásoló tényezők között önálló rizikófaktor a donorszerv minősége $[2,3]$, az ischaemiás-reperfúziós károsodás [4] és a posztoperatív időszakban kialakuló közép-, hosszú távú szövődmények. Ez utóbbiak közé tartozik a diabetes mellitus, a nem megfelelően kezelt magas vérnyomás, a vese keringését érintő anomáliák, illetve az antitestmediált rejekció (ABMR) [5]. Az ABMR diagnosztikája összetett, és az egyes központokban változó. A felismert és definiált ABMR lehet korai (akut) és késői (krónikus). Míg az akut esetek kezelése reményteli, a krónikus ABMR több szerző véleménye szerint a transzplantációs glomerulopathia szövettani diagnózisának hátterében meghúzódó leggyakoribb klinikai ok. A korai ABMR kezelése terén is megoszlanak a vélemények, nincs egységes stratégia. A szerzők arra vállalkoztak, hogy áttekintést nyújtsanak az ABMR jelenleg ismert diagnosztikai és kezelési hátteréről.

\section{Módszer}

Munkánk természetéből adódóan nem a saját beteganyag elemzését helyeztük a középpontba, hanem a tárgyban megjelent közlemények rendszerezését és áttekintését. A közleményt három fejezetre osztottuk: az ABMR kialakulásának háttere, diagnosztikai eszközök, és kezelési le- 
hetőségei. Saját szakmai anyagot két hazai vesetranszplantációs centrumtól tudtunk beszerezni. A debreceni és a pécsi eredményeket az 1. táblázatban mutatjuk be. A 2013 és 2017 között vesetranszplantált betegek alapvető adatait elemeztük. Az ABMR diagnózisát akkor tekintettük bizonyítottnak, ha a betegnél szövettani vizsgálat történt, amely ezt igazolta. A betegek legfontosabb kezelési adatait gyüjtöttük, az orvosi dokumentáció (MedSolution) alapján. Az alacsony esetszám miatt statisztikai elemzést nem minden esetben végeztünk. A kimenetelt legalább 6 hónapos utánkövetésre alapoztuk.

\section{Eredmények}

A megadott periódusban (2013-2017) a két veseátültető központban összesen 454 kadávervese-átültetés történt (Debrecen: 230; Pécs: 224). A klinikai tünetek miatt végzett szövettani vizsgálat alapján akut antitestmediált rejekció diagnózisát 18 betegnél állítottuk fel (Debrecen: $8 ; 3,5 \%$; Pécs: 10; 4,5\%), ez átlagosan 4\%. A betegek átlagéletkora (Debrecenben 46,4; Pécsen 54,8) $51,2 \pm 6,6$, év volt. A veseátültetés után az ABMR diagnózisáig eltelt idő (Debrecenben 17,0; Pécsen 11,2) átlagosan 15,4 \pm 22 , 1 hónap volt. Az ABMR-esetek 22\%-a volt primer átültetés és $78 \%$ retranszplantált. C4d-pozitivitást 7 esetben sikerült igazolni, ami az összes ABMReset 39\%-a: Debrecenben $5(62,5 \%)$, Pécsen $2(20 \%)$ betegnél. A két centrumban összesen 16 betegnél tör- tént szteroidbolus + IVIG + PF kezelés (Pécs: 10, Debrecen: 6). A 6 debreceni beteg közül 5 kapott ezenfelül rituximabot, egy pedig alemtuzumabot, míg a 10 pécsi beteg közül ezt a kezelést egynél sem alkalmazták. Pécsen viszont 2 beteg részesült antithymocytaglobulin-kezelésben is a fenti séma mellett. Debrecenben 2 további beteg esetén nem történt klasszikus PF + IVIG kezelés, csak takrolimusz + mTOR-inhibitor együttes alkalmazása és szteroidbolus alkalmazása. A kezelésre reagáló, gyógyult eseteknél csak egy esetben (8\%) nem volt HLA II. osztályú egyezés, 5 esetben $(38 \%)$ viszont 2 DRegyezés volt. A kezelésre nem reagáló, művesekezelésre visszakerült, azaz graftvesztéssel járó eseteknél egy esetben nem volt DR-egyezés (20\%), és egy betegnél sem volt teljes DR-egyezés.

A kezelt betegek közül 11 betegnél $(61,1 \%)$ a kezelés hatására rövid távon javuló vesefunkciót észleltünk (Debrecen: 5; Pécs: 6), 6 esetben $(33,3 \%)$ romlást (Debrecen: 2; Pécs: 4$)$. Egy beteg az utánkövetés alatt, rövid időn belül meghalt Debrecenben. A teljes utánkövetés végén ( 6 hónap) 17 beteget figyeltünk meg. $9(47,4 \%)$ beteg él múködő beültetett vesével (Debrecen: 5; 62,5\%; Pécs: $4 ; 40 \%$ ), 4 beteg meghalt, ez 21\% (Debrecen: 1; 12,5\%; Pécs: $3 ; 27,3 \%$ ), és 5 beteg került vissza múvesekezelésre graftvesztés miatt, 31\% (Debrecen: 2; 25\%; Pécs: $3 ; 33,3 \%)$.

A debreceni központban transzplantált betegeknél részletesebb elemzést is végeztünk. Az 1. táblázatban

1. táblázat | A Debreceni Transzplantációs Centrumban 2013-2017 között antitestmediált rejekcióval kezelt betegek adatai: DSA-karakter, MFI, graftkárosodás a szövettani eltérések függvényében, alkalmazott immunszuppresszív kezelés, kimenetel

\begin{tabular}{|c|c|c|c|c|c|c|c|c|}
\hline & 1. beteg & 2. beteg & 3. beteg & 4. beteg & 5. beteg & 6. beteg & 7. beteg & 8. beteg \\
\hline Transzplantáció & $1 \mathrm{tx}$ & $2 \mathrm{tx}$ & $2 \mathrm{tx}$ & $2 \mathrm{tx}$ & $1 \mathrm{tx}$ & $2 \mathrm{tx}$ & $2 \mathrm{tx}$ & $2 \mathrm{tx}$ \\
\hline DSA ismert & + & + & + & + & + & + & + & + \\
\hline HLA I. & + & + & + & + & - & + & + & + \\
\hline HLA II. & - & + & + & + & + & + & + & - \\
\hline MFI & 1550 & $5000-13000$ & $5000-9000$ & $4000-11000$ & 14000 & $6000-18000$ & $3000-4000$ & $500-3000$ \\
\hline \multicolumn{9}{|l|}{ Allograftkárosodás } \\
\hline C4d-pozitivitás & + & - & $\begin{array}{l}\text { Gyenge, } \\
\text { közepes }\end{array}$ & Diffúz, erôs & $\begin{array}{l}\text { Diffúz, } \\
\text { közepes }\end{array}$ & - & - & $\begin{array}{l}\text { Gyenge, } \\
\text { közepes }\end{array}$ \\
\hline $\begin{array}{l}\text { Mikrocirkulációs } \\
\text { gyulladás }\end{array}$ & Enyhe & Enyhe & Mérsékelt & Mérsékelt & Mérsékelt & Enyhe & Enyhe & Enyhe \\
\hline Arteriitis & Minimális & Minimális & Minimális & + & + & Minimális & - & Minimális \\
\hline Arterialis hyalinosis & - & - & Enyhe & + & + & - & - & - \\
\hline Fibrosis, atrophia & - & - & + & + & + & - & - & - \\
\hline $\mathrm{CV}$ & $\mathrm{cvl}$ & $\mathrm{cvl}$ & $\mathrm{cv} 2$ & $\mathrm{cv} 2$ & $\mathrm{cv} 2$ & $\mathrm{cv} 0$ & $\mathrm{cv} 0$ & $\mathrm{cvl}$ \\
\hline Kezelés & $\begin{array}{c}\text { mTOR + } \\
\text { TAC } \\
\text { Szteroid- } \\
\text { bolus }\end{array}$ & $\begin{array}{c}\mathrm{PF}+\mathrm{IVIG} \\
\mathrm{rMAB}\end{array}$ & $\begin{array}{c}\text { PF + IVIG, } \\
\text { rMAB + } \\
\text { alemtuzumab }\end{array}$ & $\begin{array}{c}\mathrm{PF}+\mathrm{IVIG}, \\
\mathrm{rMAB}\end{array}$ & $\begin{array}{c}\mathrm{PF}+\mathrm{IVIG} \\
\mathrm{rMAB}\end{array}$ & $\begin{array}{c}\mathrm{PF}+\mathrm{IVIG}, \\
\mathrm{rMAB}\end{array}$ & $\begin{array}{l}\text { mTOR + } \\
\text { TAC } \\
\text { Szteroid- } \\
\text { bolus }\end{array}$ & $\begin{array}{c}\mathrm{PF}+\mathrm{IVIG}, \\
\mathrm{rMAB}\end{array}$ \\
\hline Kimenetel & $\begin{array}{c}\text { Jó } \\
\text { graftfunkció }\end{array}$ & $\begin{array}{c}\text { Jó } \\
\text { graftfunkció }\end{array}$ & $\begin{array}{l}\text { Graftvesztés, } \\
\text { dialízis }\end{array}$ & $\begin{array}{c}\text { Graftvesztés, } \\
\text { dialízis }\end{array}$ & $\begin{array}{c}\text { Jó } \\
\text { graftfunkció }\end{array}$ & $\begin{array}{c}\text { Jó } \\
\text { graftfunkció, } \\
\text { DSA: } \\
3000 \text { MFI }\end{array}$ & $\begin{array}{c}\text { Jó } \\
\text { graftfunkció, } \\
\text { DSA: } \\
1500 \mathrm{MFI}\end{array}$ & Exit \\
\hline
\end{tabular}

$\mathrm{CV}=$ krónikus vascularis eltérés (cv0: nincs krónikus vascularis eltérés; cvl: a vasculatura 25\%-nál kisebb mértékben érintett a fibrointimalis artéria vastagodása által; cv2: 26-50\%-a érintett; cv3: 50\%-nál több érintett); DSA = donorspecifikus antitest; HLA = humán leukocytaantigén; IVIG = intravénás immunglobulin; MFI = átlagos fluoreszcenciaintenzitás; $\mathrm{PF}=$ plazmaferézis; rMAB = rituximab 
látszik, hogy akut ABMR esetén a betegek döntő többsége (a 8-ból 6) 'second' transzplantált volt, azaz a második veseallograft beültetése után alakult ki az akut antitestmediált rejekció. Ez nem meglepő, hiszen az ABMR megjelenésére hajlamosít a preszenzitizált állapot. Betegeink közül csak két esetben nem volt a vese átültetésekor HLA II. osztályú (azaz DR- vagy DQ-) egyezés a donor és a recipiens között. Ez lényeges abból a szempontból, hogy az ABMR megjelenését valóban nem kötik a hagyományosan „jó egyezésnek” tekintett DR locusú donor-recipiens azonosság hiányához. A HLA II. osztályú egyezés megléte inkább a celluláris típusú kilökődés esetében tekinthető protektív hatásúnak. Ha a kimenetel szempontjából vizsgáljuk az adatokat, az látszik, hogy a 8 kezelt beteg közül csak kettőnél alakult ki végül graftelégtelenség. Egy beteg meghalt akut, cardiovascularis okra visszavezethetően, de ennek nem volt köze sem az ABMR-hez, sem a kezeléshez. Ez a beteg kapott alemtuzumabot. Tehát a kezelés a betegek túlnyomó többségénél hatékony volt, legalábbis rövid és középtávon. Azon betegek közül, akiknél az ABMR kezelése után jó graftmúköodést tapasztaltunk, 2 esetben volt alacsony a kezelés előtt mért DSA MFI-je (1550 és 4000), míg 3 betegnél kifejezetten magas (13 000, 14 000, 18 000). Azoknál, akiknél később graftvesztés következett be, mindkét esetben magas volt az MFI (9000 és 11 000). A graftvesztéssel záruló eseteknél a kezelés alapjául szolgáló szövettani mintában mindkét esetben pozitív volt a C4d (az egyiknél gyengén, a másik esetben erősen), míg a jó graftműködéssel végződő esetek közül három C4d-negatív volt, kettő C4d-pozitív (diffúz, közepes). Mindkét betegnél, aki az ABMR miatt elveszítette a graftot, a mikrocirkulációs gyulladás szemikvantitatív értékelése mérsékelt/közepes pozitivitást mutatott, míg a legtöbb gyógyult betegnél ez eleve enyhe volt vagy hiányzott. Hasonlóan az arteriitis jelei és főleg a fibrosis kialakulása mindkét graftvesztett esetben pozitív volt, míg gyógyulás esetén a négyből csak egy esetben voltak ilyen jelek. Ugyanezt az eloszlást mutatják a krónikus vascularis eltérés pontszámai. A kezelés tekintetében nem ilyen egyértelmű az összefüggés. A graftvesztéssel záruló esetekben mindkét beteg megkapta a jelenleg hazánkban elérhető legmodernebb kezelést (sorozatos plazmaferézis, IVIG, rituximab és az egyik betegnél még alemtuzumab is). Az utánkövetés során hatékonynak talált kezelés (jó graftmúködés) az öt ilyen eset közül kettőben a takrolimusz mellett mTOR-inhibitor bevezetése, szteroid-lökésterápia volt, három esetben pedig az előbb említett kombinált kezelés (PF + IVIG + rMAB). A táblázatban nem szerepel, de a szövettani jelekből indirekt módon is látszik, hogy a graftvesztéssel járó esetekben a diagnózis felállításakor a folyamat már előrehaladott stádiumban volt. Ezeknél a betegeknél a vizsgálatokat megelőzően már fellépett a proteinuria (microalbuminuria), és visszatérően emelkedett a szérumkreatinin.

\section{Megbeszélés}

A közleményünknek - az alacsony hazai esetszámból és a vizsgálati módszerből adódóan (nem randomizált nem kontrolláltan tervezett prospektív vizsgálat) - nem célja saját eredmények alapján levonni stratégiai következtetéseket, inkább áttekintést szeretnénk adni az ABMR problematikájával kapcsolatos ismeretekről. A témával foglalkozó színvonalas közlemények között több hazai szerző közleménye is fellelhető, így Remport és mtsai 2015-ben írt összefoglalója, melynek kitekintésére szintén támaszkodtunk [6]. Vizsgálatunk korlátai ellenére néhány szerény következtetés levonható a saját adatokból is, melyeket közleményünk végén, a Következtetésekben teszünk meg.

\section{Az ABMR kialakulásának háttere, diagnosztikai eszközök}

\section{Immunológiai háttér}

\section{A T-sejt-alcsoportok szerepe}

A T-sejt-mediált alloimmunitás kontrollja a modern immunszuppresszív gyógyszerek korában rutinfeladat. A T-sejt-aktivitást feltételező akut celluláris rejekció ritka. Ezzel szemben a B-sejt-vonallal összefüggő humorális vagy antitestmediált rejekció szerepe izgalmas és új területe a kutatásnak, a donorspecifikus antitestek (DSA) kialakulásával együtt.

Az ABMR már 4-6 nappal a veseátültetés után is kialakulhat. A CD8+-sejtek a graft APC-sejtjének MHC I. komplexéhez kapcsolódnak, direkt citotoxikus hatásúak, endotheliitist, thrombosist, graftischaemiát okoznak. Az indirekt útvonal központi szereplői a CD4+-sejtek, melyek az APC-sejt MHC II.-vel kapcsolódnak össze, s IFN $\gamma$ termelődésén keresztül, citokintermelés által makrofágaktivációt okozva, indirekt módon fejtik ki sejtkárosító hatásukat. A CD4+-sejtek aktiválják a B-lymphocytákat, amelyek antitest-termelődéssel fogják kijelölni, mintegy „zászlóként” megjelölni a vese endotheliumában a destrukció helyét [7]. Az egyes T- és B-sejt-alcsoportok a transzplantációs immunológiai állapotnak megfelelően különböző arányban/számban és aktiváltsági fokban lehetnek jelen. Megfigyelték például, hogy krónikus allograftnephropathiában (CAN) a CD8+-sejtek aránya szignifikánsan megnövekszik [8]. A kalcineurininhibitorok (CNI) hatására csökken a CD19+-sejtek (azaz a B-sejtvonal) és ezen belül a regulatorikus B-sejtek aránya, és az általuk termelt interleukin-2 mennyisége is [9], ugyanakkor emelkedik vagy stagnál a regulatorikus T-sejtek aránya. Ennek azért lehet jelentősége, mert közlések szerint a beültetett veseallograft hosszú távú múködése és a tranzicionális B-sejtek [CD19 (+) CD24(hi) CD38(hi)] száma között pozitív összefüggést találtak [10]. 


\section{A donorspecifikus antitestek szerepe}

Az ABMR kialakulásában elsődleges szerepe van a recipiens immunrendszere és az allograft között interfészként funkcionáló endotheliumon expresszálódó antigének ellen irányuló, ellenanyagoknak. Az alloantitestek patogén szerepének felismerése az 1960-as évekre nyúlik vissza, amikor összefüggést mutattak ki a komplementdependens citotoxicitás (CDC) módszerével detektálható donorspecifikus antitestek és a hiperakut rejekció között. A módszer sok helyen máig gold standardnak számít. A CDC-módszert később az érzékenyebb enzyme-linked immunosorbent assay (ELISA) és áramlási citometriás módszerek követték, míg mára a DSA-k kimutatásában az úgynevezett 'single antigen beads' módszer vált talán a legelterjedtebbé (Luminex-SAB) a CDC-módszer mellett, illetve részben azt kiszorítva [11]. A SAB-módszer multiplex mérési módszer, amelyben fluoreszcens gyöngyök felszínéhez kötötten közel 200 HLA antigén segítségével történik az egyén alloantitest-repertoárjának meghatározása. Ez a jelenleg elérhető legérzékenyebb módszer, amit jól demonstrál Gombos és mtsai tanulmánya. A vizsgálatban 534 , vesetranszplantációs várólistán lévő betegnél hasonlítottak össze három, a HLA-ellenes antitesteket vizsgáló módszert. A betegek 5\%-a CDC-, 14\%-a ELISA- és 81\%-a SAB-pozitívnak bizonyult, ami jól mutatja a módszerek közötti érzékenységbeli különbséget [12]. A SAB-pozitív betegek 77\%-ának esetében a HLA-antitest jelenlétét semmilyen múltbéli immunizációs eseményhez nem tudták kötni. A pozitivitási küszöbértéket 1000 MFI-rôl 2000 MFI-re emelve ez az arány $50 \%$-ra csökkent.

$\mathrm{Az}$ úgynevezett $\mathrm{Clq}$-módszer a $\mathrm{SAB}$-módszer érzékenységét és a CDC-módszer elônyeit hivatott ötvözni, mert csak a klinikailag leginkább relevánsnak tartott, komplementkötő antitesteket mutatja ki. Amellett, hogy érzékenyebb, mint a CDC, értékes abból a szempontból is, hogy a Clq-pozitív l-es osztályú HLA-antitesteknek jelentőséget tulajdonítanak az ABMR előrejelzésében és a glomerulopathia kialakulásában [13]. A C3d-komplement-kötés vizsgálatát újabban a Clq-nál is érzékenyebbnek tartják [14].

A HLA-ellenes antitestek mellett egyre nagyobb irodalma van a non-HLA-ellenanyagoknak, amelyek a betegek 10-40\%-ának esetében megjelenhetnek az antitestmediált folyamatokban. A non-HLA-ellenanyagok klinikai relevanciájára a 2000-es évek elején kezdtek felfigyelni. A 245 centrum eredményét összefoglaló Collaborative Transplant Study közleményben a HLA-identikus testvér donortól származó vesetranszplantációt követően szignifikánsabb magasabb 10 éves grafttúlélést mutattak ki a PRA-negatív betegek esetében (3001 fó) a PRA 1-50\% (803 fó) és a PRA 50\% feletti értékkel rendelkező betegekhez (244 fö) képest ( $p=0,0006$ és $\mathrm{p}<0,0001)$ [15]. A szerzők feltételezték, hogy a korai graftvesztés hátterében non-HLA-antitestek játszhatnak szerepet. Mára már számos non-HLA antigént azonosítottak, melyeknek bizonyított szerepük van az ABMR kialakulásában. A témában több kiváló összefoglaló látott napvilágot [16]. A legjelentősebb non-HLA antigének a G-protein coupled receptor (GPCR) családjába tartozó angiotensin II type l receptor (ATIR) és az endothelin type A receptor (ETAR) fehérjék, extracelluláris fehérjék, valamint a MIC (MHC Class I-related chain) antigének.

Egyes közlemények kiemelik az újonnan, de novo keletkező DSA-k szerepét a korai/akut ABMR és a transzplantációs glomerulopathia (TGP) kialakulásában [17]. Az biztos, hogy a donorvese epitheliumán a HLA-ellenes DSA-k megjelennek, de a korábbi várakozások ellenére az derült ki, hogy a - kimutatott - IgG típusú HLAantitestek közül nem mindegyiknek van köze az ABMR-hez. In vitro vizsgálatok során felmerült, hogy az anti-HLA antitestek komplementet (C4d, Clq, C3d) aktiváló hatástól függően befolyásolják a vesegraft túlélését: a komplementkötő antitestek ártalmas hatása gyorsabban manifesztálódik, mint a komplementet nem kötő antitesteké [18]. Abban konszenzus észlelhető, hogy az ABMR és a TGP felelős az akut és a késói graftvesztések jelentôs hányadáért [19].

Az újonnan megjelenő DSA-k erôs összefüggést mutatnak a B-sejtek szérumban mérhető jelenlétével és aktivitásával. Tudjuk, hogy a B-sejtek több módon is képesek befolyásolni az alloimmun folyamatot: 1) átalakulhatnak antitesttermelő plazmasejtekké; 2) fenntartják a hosszú távú humorális immunológiai memóriát; 3) antigénprezentáló sejtekké válhatnak, ami a T-sejtes immunitási vonalat is triggereli; 4) harmadlagos lymphoid szervekben felhalmozódhatnak (például nyirokcsomók); 5 ) proés antiinflammatoricus citokineket termelhetnek [19]. Néhány közlemény alapján feltételezhető, hogy nem minden B-sejt-vonal felelős a DSA termelódésért. A perifériás memória-B-sejtek és a csontvelőben lévő plazmasejtek biztosan képesek erre. Ez arra enged következtetni, hogy az alloantitest-képződés a legnagyobb valószínúséggel mindkét sejtvonalat érinti. Az antiCD20-antitest-alapú kezelések nem egyformán érintik a két sejtvonalat, ami azt jelenti, hogy a személyre szabott immunszuppresszióval kapcsolatos további kutatásoknak létjogosultságuk van [5]. A fentiek ellenére úgy tünik, hogy az ABMR súlyossága, klinikai lefolyása, valamint a de novo DSA-k megjelenése és MFI-értékük közötti öszszefüggés nem annyira erős, mint várták [20]. De Serres és mtsai 35 gyermekvese-átültetést vizsgáltak, ahol a páciensek mind alemtuzumab indukciós kezelést kaptak; később a CNI és a szteroid is visszavonásra került. A betegek 20\%-ában alakultak de novo HLA-ellenes antitestek, anélkül azonban, hogy ez a beültetett vese múködését és a 2 évvel a mútét után vett biopszia alapján értékelt szövettani eredményt befolyásolta volna [21]. Todeschini és mtsai közleménye alapján alemtuzumab indukciós kezelés mellett magasabb volt a de novo anti-HLA DSA-k megjelenési aránya, mint baziliximab vagy alacsony dózisú ATG alkalmazása esetén [22]. 


\section{Egyéb biomarkerek}

A biomarkerek vizsgálata vesetranszplantáltaknál az 1980-as években kezdődött a vizeletben lévő enzimek vizsgálatával, mint például aminopeptidáz, mikroprotein, béta-glükoronidáz a rejekciós epizódoknál. Különböző immunológiai noninvazív módszerekkel azóta több mint 15000 biomarkert vizsgáltak szervátültetetteknél [23]. A laboratóriumi technológia fejlődésével - mint például RTPCR, tömegspektrofotometria, in situ hibridizáció, ELISPOT, flow-cytometria - széles körben tudtak elterjedni az ez irányú kutatások. A proximalis kanyarulatos csatornákban akut tubularis necrosis során aktivált neutrophil granulocyták akkumulálódnak, amelyek neutrophil zselatináz asszociálta lipokalint (NGAL) termelnek, és ennek szintje a vizeletben szignifikánsan magas az akut tubularis necrosis során [24]. A vér- és vizeletmintában mért Fas-ligand, granzim B (GZMB) és perforin (PRF) szignifikáns emelkedését tapasztalták akut rejekció során [25].

A biomarkerek kutatása fontos szerephez juthat annak érdekében, hogy prediktív faktorként lehessen használni óket. Bizonyítottnak túnik, hogy a B-sejtek felszíni káliumcsatornáinak expressziója változik a sejt érési folyamata során. A naiv és az $\operatorname{IgD}(+) \mathrm{CD} 27(+)$ memória-B-sejtek felszínén a feszültségfüggő $\mathrm{Kvl}$.3- és a $\mathrm{Ca}^{++}$-aktivált közepes vezetőképességú IKCal-ioncsatornák expressziója nyugalmi állapotban alacsony, miközben az IKCalexpresszió 45 -szörösre emelkedik aktiválódás esetén, a Kvl.3-szintek változása nélkül. Ezzel szemben a memória-B-sejtek nyugalmi állapotban magas $\mathrm{Kvl}$.3-szintet expresszálnak, és az aktiválódás után is fenntartják ezt. Specifikus Kvl.3- és IKCal-inhibitorok elvileg hasznosíthatók lennének az egyes lymphocyta-alcsoportok kiiktatására immunológiai betegségekben [26]. A Kvl.3csatornát blokkoló klofaziminnel kapcsolatban megjelentek közlemények krónikus graft versus host betegség [27], SLE [28], psoriasis [29] és Crohn-betegség [30] kezelésére vonatkozóan.

Roedder és mtsai 2014-ben kifejlesztettek egy egyszerú kvantitatív PCR-tesztet, amelyet Kidney Solid Organ Response Test-nek (kSORT) neveztek el, és amely arra szolgál, hogy előre jelezze az akut rejekció kialakulását, illetve segítse a terápiás döntéshozatalt. A multicentrikus vizsgálat során 436 felnőttből származó, 558 perifériás vérmintát dolgoztak fel (AART study). Ez az elemzés 13 különböző, egyenként 12 gént tartalmazó kombinációt eredményezett, amelynek során a prevalidációs eljárás során bevont 17 génből 15-öt alkalmaztak: CEACAM4, CFLAR, DUSPI, EPOR, GZMK, ITGAX, MAPK9, NAMPT, NKTR, PSENI, RARA, RHEB, RXRA, RYBP, SLC25A37. A legfontosabb hét - úgynevezett 'core' gén a következő volt: CEACAM4, CFLAR, EPOR, GZMK, NKTR, PSEN1, SLC25A37. A szerzők ugyanakkor hangsúlyozzák, hogy a kSORT nem alkalmas a celluláris és a humorális rejekció közötti különbségtételre [31].
A modern kutatások tárgya a mikro-RNS-profil vizsgálata. Egy holland tanulmány noninvazív módon vizeletből vett minták segítségével vizsgálta, van-e összefüggés a mikro-RNS-ek jelenléte és a vesetranszplantált betegek akut rejekciója között. Azt találták, hogy a vizelet miR-210-szintje szignifikánsan alacsonyabb volt azokban a betegekben, akiknél akut T-sejt-mediált rejekció volt ismert [32]. A mikro-RNS-eket több területen hozták kapcsolatba a szervátültetéssel, így összefüggést mutattak ki a beültetett májban kialakuló fibrosissal [33], veseátültetés esetén a tubularis necrosissal (TN) és az interstitialis fibrosissal (IF). Zununi Vahed és mtsai 53, élödonoros vesetranszplantált beteget vizsgáltak szigorú kritériumrendszer mellett. (Csak azokat a betegeket válogatták be, akik 21 és 60 év között voltak. Kizárásos kritérium volt a DM; a HIV-, HBV-, HCV-, CMV-IgGszeropozitivitás; súlyos bakteriális fertőzés; ismert tumor az anamnézisben; vesegraft-obstrukció; gyulladásos betegség; autoimmun betegség.) Az 53 beteg közül 26ban volt IF és TN, 27-nek volt stabil vesefunkciója, valamint 15 nem transzplantált, egészséges alanyt vizsgáltak. Minden esetben vettek plazmamintát; a károsodott graftok diagnosztikáját és stádiumbeosztását szövettani mintavételezéssel támasztották alá $(\mathrm{n}=26)$. A plazma miR2l-szintje szignifikánsan magas volt a károsodott graftok esetében a korai stádiumban (grade I), a későiben azonban már nem (grade III). A plazma miR-21-szintje negatívan korrelált $(\mathrm{r}=-0,432 ; \mathrm{p}=0,03)$ a szérumkreatininnel, és pozitívan korrelált a GFR-rel $(\mathrm{r}=0,423 ; \mathrm{p}=$ $0,03)$ [34]. Ez arra enged következtetni, hogy egyes, plazmában keringő mikro-RNS-ek korai stádiumban jelezhetik a graftkárosodást [35]. A mikro-RNS-ek kimutathatók voltak szérumból, szövetből és vizeletmintából is. A krónikus allograftnephropathia (CAN) szérumban detektálható biomarkereként azonosították a miR-150et, a miR-192-t, a miR-200b-t és a miR-423-3p-at [36]. Millán és mtsai 80 transzplantáltat vizsgáltak két spanyol és két német centrumban. A vizeletben detektált miR142-3p-, miR-210-3p-, miR-155-5p- és CXCLl0-szintet a transzplantáció utáni 1-6 hónapig kutatták havi bontásban. A vizeletben detektált miR-155-5p és CXCL10 a rejekció kialakulására és a terápiás válaszadási készségre jellemző prognosztikai faktorként került közlésre [36]. Az ABMR vonatkozásában Iwasaki és mtsai közleménye lehet érdekes, akik szerint a miR-142-5p és a miR-486-5p a krónikus ABMR korai diagnózisának markere lehet [37].

\section{Az ABMR hisztopatológiai vonatkozásai}

Az ABMR graftkilökődés hisztológiai diagnosztikájában a Banff-klasszifikációt használjuk, amely az évek során számos módosításon ment keresztül. Míg a 2007. évi Banff-klasszifikáció alapján az ABMR-hez a peritubularis kapillárisok C4d-pozitivitása (1. ábra) mellett microvascularis gyulladásra (MVI; glomerulitis és/vagy peritubularis capillaritis), DSA meglétére volt szükség, addig a 


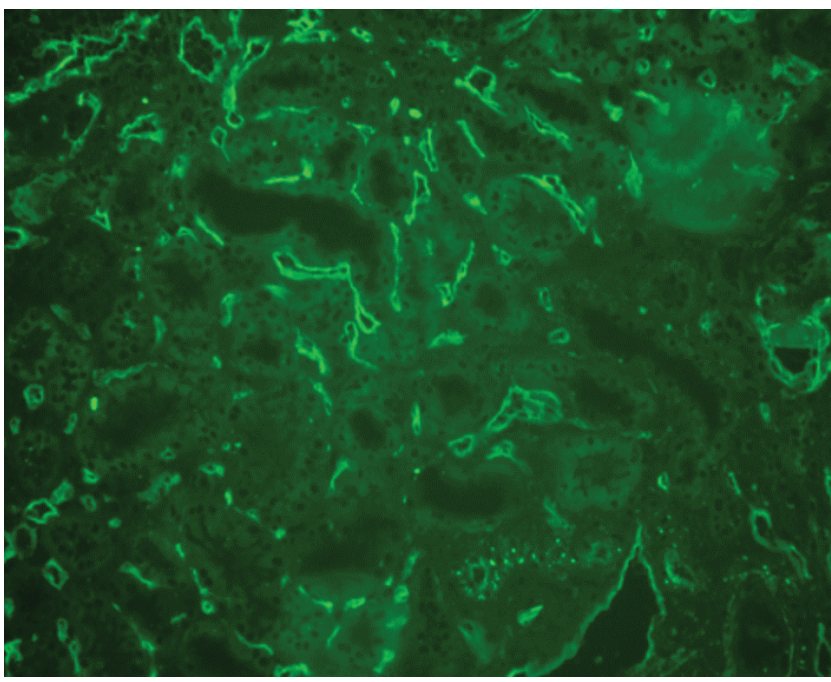

1. ábra

Komplement $(\mathrm{C} 4 \mathrm{~d})$ lerakódás a peritubularis kapillárisokban (Cd4-ellenes antitestek immunfluoreszcens vizsgálati módszer) (saját anyag)

2013. évi Banff-klasszifikáció bevezette a C4d-negatív ABMR fogalmát. Számos további vizsgálat az MVI és a grafttúlélés között szoros összefüggést igazolt. Ugyanakkor a klinikai gyakorlatban számos DSA-negatív, a szövettani kritériumok alapján ABMR-re utaló esetben (MVI $\geq 1$, C4d-pozitív; MVI $\geq 2$, C4d-negatív) fölmerült a kérdés, hogy mit kellene tenni. Ilyen esetekben a nonHLA-ellenes antitestek szürése javasolt, viszont ez sok centrumban nem érhető el, és klinikai jelentősége sem teljesen tisztázott. Míg az ABMR diagnosztikájában a C4d szenzitivitása limitált felismerésre került, és a C4dnegatív ABMR-csoportnak a 'Banff 2013'-ba való beillesztéséhez vezetett, addig számos vizsgálat megmutatta, hogy fagyasztott metszeten végzett C4d immunfluoreszcens (IF) vagy paraffinba ágyazott metszeten végzett C4d immunperoxidáz (IP)-pozitív reakciónak DSA meglétére nagyon magas a specificitása $(90 \%$ feletti). A további vizsgálatok alapján, natív vagy preimplantációs ('nullidős') vesékből származó biopsziás mintákban C4d fals pozitivitás nem igazolódott. Mindezekból kiindulva, fagyasztott metszeteken vizsgálva, a peritubularis kapillárisok legalább $10 \%$-ában látott ++ vagy +++ intenzitású C4d-pozitivitás vagy paraffinba ágyazott mintában bármilyen kiterjedésú és intenzitású pozitivitás, MVI megléte mellett, DSA-negativitás esetében is elégséges az ABMR diagnózisához. Hidalgo és mtsai [38] DSA-pozitív és DSA-negatív esetekben differenciáltan expresszálódó mRNS detektálására alkalmas „DSAspecifikus” transzkripciós szettet (DSAST) vezettek be. A C4d és a DSA meglététől független ABMR detektálására specifikusabb markernek bizonyult a Loupy és mtsai [39] által bevezetett, 30 nem redundáns próbát tartalmazó ABMR-osztályozó. A technológia előretörésével e génszettek vagy -osztályozók megfelelő validációs vizsgálatok után potenciálisan alkalmasak lehetnek az ABMR 3. kritériumának kielégítésére. A szövettani jellegzetességeknél kiemelendők a glomerulusokat, a peritubularis kapillárisokat, az artériákat, az interstitiumot, illetve a tubulusokat érintő specifikus, illetve aspecifikus eltérések [40]. A glomerulusokban az úgynevezett „glomerulitis” hátterében neutrophil granulocyták túlsúlya mellett monocytafelhalmozódás, duzzadt endothelsejtek, illetve mitotikus aktivitás figyelhető meg. Emellett a glomeruluskapilláris-kacsokban nemritkán fibrinthrombus, illetve thrombus kialakulása mellett néha mesangiolysis is előfordul. A peritubularis kapillárisok részéről mérsékelt fokú a dilatatio, illetve a szintén neutrophildomináns mononukleáris sejtes beszűrődés, amelyet „peritubularis capillaritis"-ként említünk. Az artériák részéről fibrinoid necrosis mellett ritkán endothelialitis is előfordul, amely inkább a celluláris kilökődés jellegzetességének mondható. Az interstitium részéről enyhe idült lymphoid beszürődés mellett mérsékelt fokú vizenyő, illetve fokális bevérzés fordulhat elő. A tubulusok részérôl jellegzetesnek mondható az akut tubularis károsodás, de ritkán tubulitisre jellegzetes intraepithelialis gyulladásos sejtek, valamint luminális lokalizációban neutrophil granulocyták is előfordulnak.

A 2013. évi Banff-klasszifikációban használt akut/aktív ABMR-csoport klinikailag lehet akut, fellángolás vagy szubklinikai. Mindez a 2015. évi Banff-klasszifikációban is változatlan maradt, viszont az aktuális 'Banff 2017' alapján [41]:

Aktív ABMR; a diagnózishoz mind a három szövettani kritérium teljesülése szükséges.

1. Morfológiailag igazolt heveny szövetkárosodás; egy vagy több a következőkből:

- MVI (g>0 és vagy ptc>0) de novo vagy visszatérő glomerulonephritis hiányában, viszont akut TCMR, borderline kilökődés vagy fertőzés esetében a ptc $\geq 1$ mellé minimum $\mathrm{g} \geq \mathrm{l}$ szükséges;

- intimalis vagy transmuralis arteritis $(v>0)$;

- heveny thromboticus microangiopathia, egyébbel nem magyarázható;

- heveny tubularis károsodás, egyébbel nem magyarázható.

2. A közelmúltban lezajlott/zajló antitest-endothelsejt interakció bizonyítéka; l vagy több a következőkből:

- lineáris ptc C4d-pozitivitás $(\mathrm{C} 4 \mathrm{~d}++/+++$ IF fagyasztott metszeten, C4d>0 IP paraffinos metszeten);

- legalább mérsékelt MVI ([g + ptc $] \geq 2)$ de novo vagy visszatérő glomerulonephritis hiányában, viszont akut T-sejt-mediált rejekció, borderline kilökődés vagy fertőzés esetében a ptc $\geq 2$ mellé minimum $g \geq 1$ szükséges;

- gén transzkriptumok/osztályozók fokozott kifejeződése ABMR-rel társul (amennyiben validálták).

3. Donorspecifikus antitestek szerológiai bizonyítéka (DSA, HLA vagy egyéb). A C4d-pozitivitás a gén transzkriptumok/osztályozók fokozott kifejeződésével együtt helyettesítheti a DSA-t. Az 1. és a 2. kritérium teljesülése esetében DSA-meghatározás javasolt (HLA-negatív esetekben non-HLA is). 


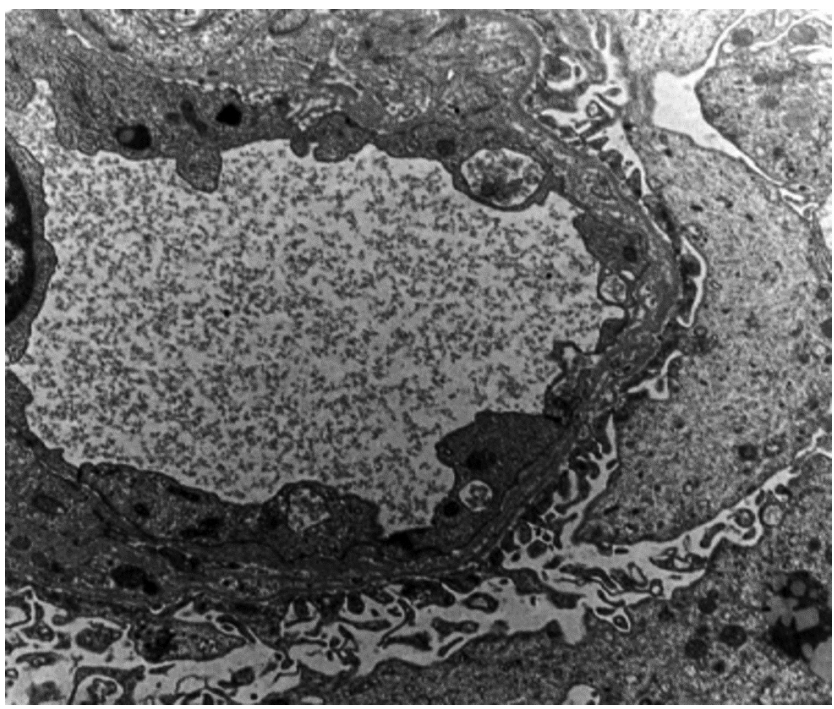

2. ábra

Krónikus antitestmediált rejekció. A glomerularis bazálmembrán rétegződését látjuk fény- és elektron-mikroszkóposan (saját anyag)

Krónikus aktív ABMR; a diagnózishoz mind a 3 kritérium teljesülése szükséges.

1. Morfológiailag igazolt krónikus szövetkárosodás; 1 vagy több a következőkből:

- transzplantációs glomerulopathia $(\operatorname{cg}>0)$ krónikus TMA, de novo vagy visszatérő glomerulonephritis hiányában, beleértve az EM-vizsgálattal igazolható eltéréseket is (cgla) (2. ábra) [42], melynek leírásában saját anyagunk mellett más centrumok hazai

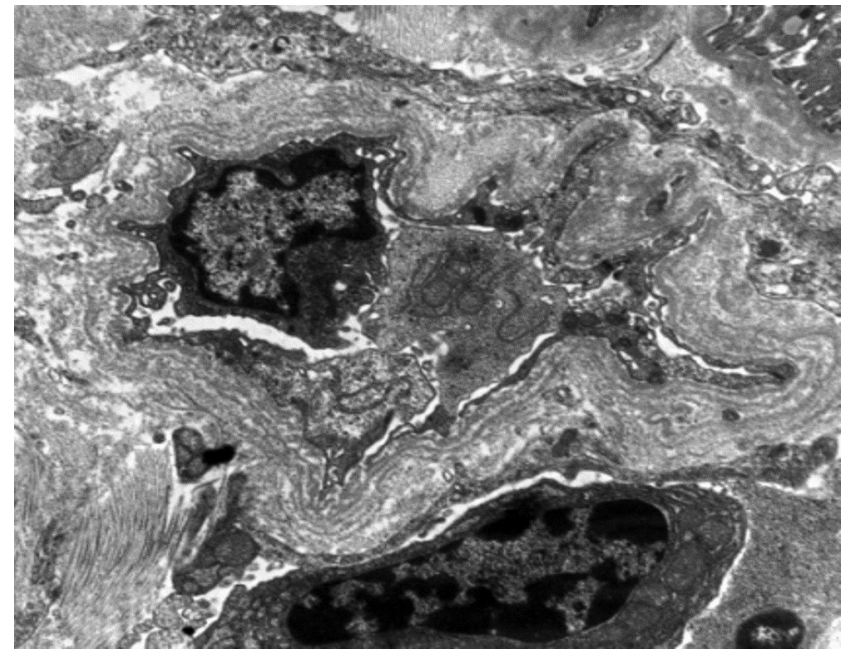

3. ábra

Transzplantációs arteriopathia. Fibrosus intimalis megvastago dásban nyilvánul meg. EM-vizsgálat során a peritubularis capil laropathia, vagyis a bazálmembrán-rétegződés jellegzetes eltérésnek mondható, amely elörehaladottabb stádiumban néha fénymikroszkóposan is detektálható (saját anyag)

szerzőinek színvonalas közlésére is támaszkodhatunk [43];

- súlyos ptc bazálmembrán-rétegződés (EM szükséges) (3. ábra);

- másként nem magyarázható, újdonképződött, artériákat érintő intimalis fibrosis; korábbi T-sejt-mediált rejekció hiányában a scleroticus intimát infiltráló leukocyták krónikus ABMR-re utalnak.

2. táblázat $\mid$ DSA jelenléte és az ABMR incidenciája 1119 beteg adatai alapján (Mohan S, et al. J Am Soc Nephrol. 2012; 23: 2061-2071). A feltüntetett 7 vizsgálat összegzése alapján mind az ABMR kialakulásának (bal oldali táblázat - AMR), mind a beültetett veseallograft elvesztésének kockázata (jobb oldali táblázat - graft loss) magasabb abban az esetben, ha donorspecifikus antitestek jelennek meg
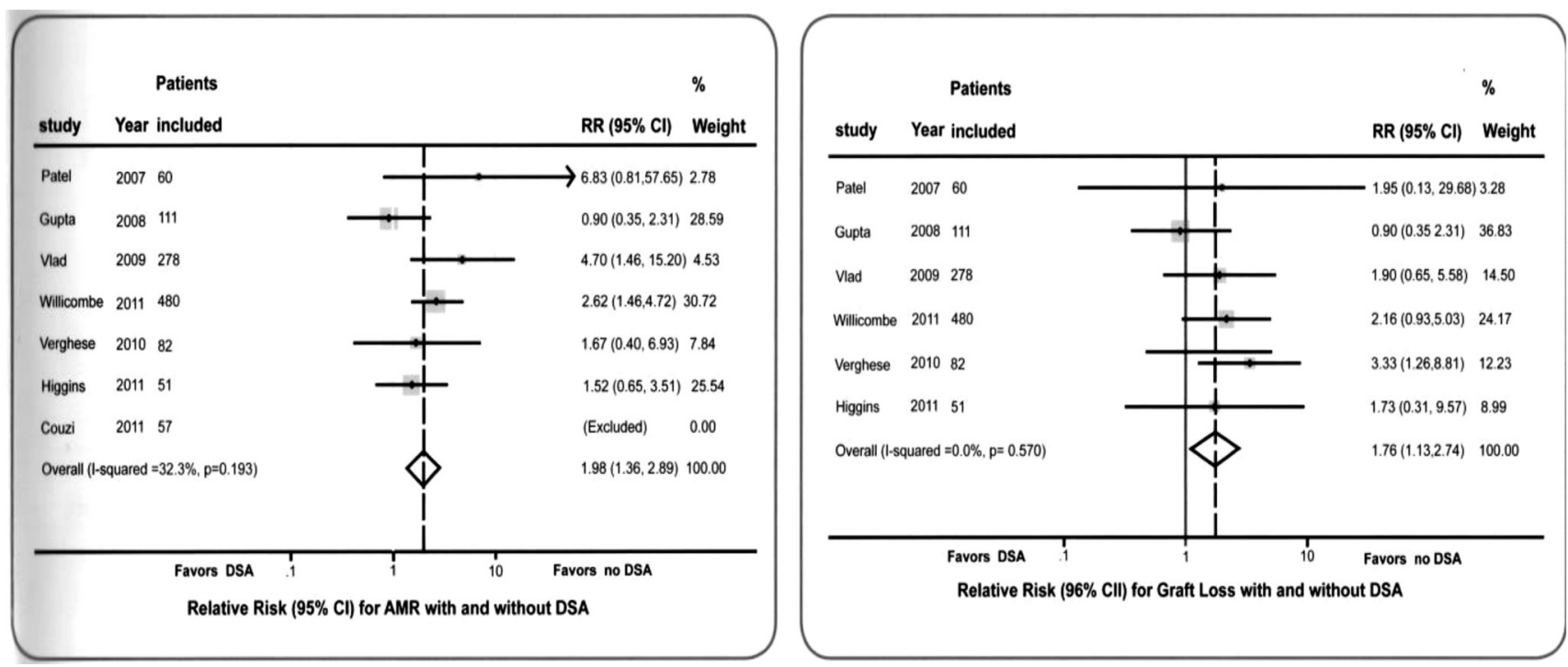

Exluded = kizárt (például beteg); Favors DSA/no DSA = DSA jelenlétét igazolja/nem igazolja; Patient = beteg; Relative risk for AMR with and without DSA = antitestmediált rejekció relatív kockázata DSA jelenlétében és DSA nélkül; Study = közlemény/tanulmány; Weight = súly (értsd: statisztikai); Year included = vizsgált év 
2. Az aktív ABMR 2. kritériumaival megegyezik, lásd fentebb.

3. Az aktív ABMR 3. kritériumaival megegyezik, lásd fentebb; az 1. vagy a 2 . kritérium teljesülése esetében DSA-meghatározás javasolt.

C4d-pozitivitás kilökődésre utaló jelek nélkül; a diagnózishoz mind a 4 kritérium szükséges.

1. Lineáris C4d-pozitivitás a peritubularis kapillárisokban $(\mathrm{C} 4 \mathrm{~d}++/+++$ IF fagyasztott metszeten, $\mathrm{C} 4 \mathrm{~d}>0$ IP paraffinos metszeten);

2. az aktív vagy krónikus aktív ABMR 1. kritériuma nem teljesül;

3. az aktív vagy krónikus aktív ABMR 2. kritériumában szereplő molekuláris vizsgálat negatív;

4. aktív vagy krónikus aktív T-sejt-mediált kilökődés, borderline kilökődés nem igazolható.

\section{Az ABMR klinikai tünetei, kórlefolyása}

Az ABMR klinikai diagnózisa magában foglalja az akut graftelégtelenség tüneteit (a kreatinin emelkedése, GFRcsökkenés), a DSA-k megjelenését és a biopszia során vett minta kórszövettani jegyeit. Az akut ABMR krónikussá válására utal a proteinuria megjelenése és a magas vérnyomás kialakulása vagy az értékek romlása egyéb ok kizárása után. A szérumban kimutatott markerek alapján felállított diagnózisnak az a hátránya, hogy szenzitivitása kérdéses, a kezelés szempontjából sokszor már elkésett, irreverzibilis a folyamat.

Az akut antitestmediált rejekciónak két típusát különböztetjük meg. Az l-es típus a már meglévő DSA, a 2-es típus a de novo képződő DSA által okozott graftkárosodást jelenti. Az l-es, vagy korai típusra jellemző, hogy a transzplantációt követően korán jelentkezik a szenzitizált betegeknél, lehet HLA I. és/vagy II. típus, a legtöbbször jó a megfelelő terápiára adott válasz. A késői humorális kilökődés a transzplantációt követően az első évet követően alakul ki, kezelhetősége meglehetősen nehéz. Az 1-es típus diagnózisa viszonylag könnyü, de a második típus kezdetét nehéz megállapítani a graftfunkció romlásának hiányában. A rutin-DSA-monitorozás, a protokollbiopszia ebben nyújt segítséget. A Banff-klaszszifikáció értelmében egy harmadik kategóriát is javasolnak, a 'lappangó' humorális rejekció formát, a meglévő akut/aktív és a krónikus aktív kategória mellé. Az új kategória: transzplantációs glomerulopathia nélküli forma, mely nem illeszthető be az akut típusba. Ennek értelmében a valódi akut esetek rendszerint a memóriaválasz, a már meglévő DSA 'rebound'-jának tartják a transzplantációt követő korai periódusban. A 'lappangó' típusba azok az esetek sorolhatók, melyek sem az akut, sem a krónikus aktív típusba nem osztályozhatók. A krónikus antitestmediált rejekción a valóban transzplantációs glomerulopathiát mutató valós idült eseteket értjük. Molekuláris diagnosztika, az endothelsejt-aktiváció vizsgálata, az NK-sejt-transzkriptumok vizsgálata segíthet a kérdéses esetek diagnosztikájában. A 2013. és a 2015. évi
Banff-klasszifikáció értelmében az akut antitestmediált rejekció klinikailag akut, lappangó, szubklinikus kategóriákba volt sorolható, azonban a 2017-es Banff-klasszifikáció aktív és krónikus típusokat fogalmaz meg [41, 44].

Az alacsony titerü DSA hatása a vesegraftmúködésre nem világos. Mohan és munkacsoportja hét retrospektív kohorszvizsgálat elemzésével megállapította, hogy a negatív flow-cytometriás keresztpróba ellenére a DSA jelenléte közel megkétszerezi az antitestmediált kilökődés rizikóját, RR: 1,98 (CI: 95\%: 1,36-2,89). A 2. táblázatban láthatók a vizsgált tanulmányok eredményei. Ezek a 2007 és 2011 közötti időszakra vonatkoznak, és 1119 beteg adatát dolgozták föl [44]. Vizsgálták azt is, hogy a DSA-titer (MFI) dinamikájának változása mennyiben különbözik azokban a betegekben, akikben kialakul antitestmediált kilökődés, azokhoz képest, akikben nem alakul ki ABMR. Zhang és munkacsoportja vizsgálata alapján

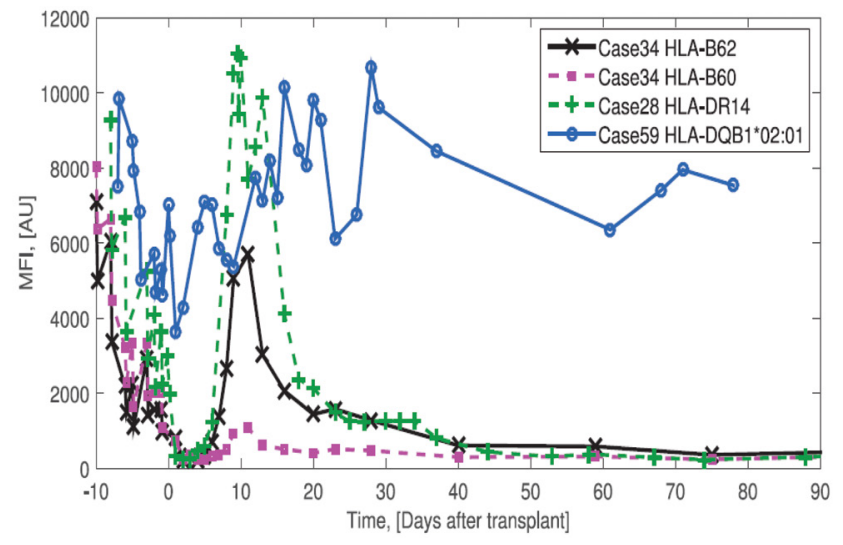

DSA-titer változása azon betegeknél, akiknél később nem alakult ki ABMR. Lát ható, hogy a legtöbb betegnél a DSA-titer a 30. posztoperatív napra visszatér az 1000 MFI alá

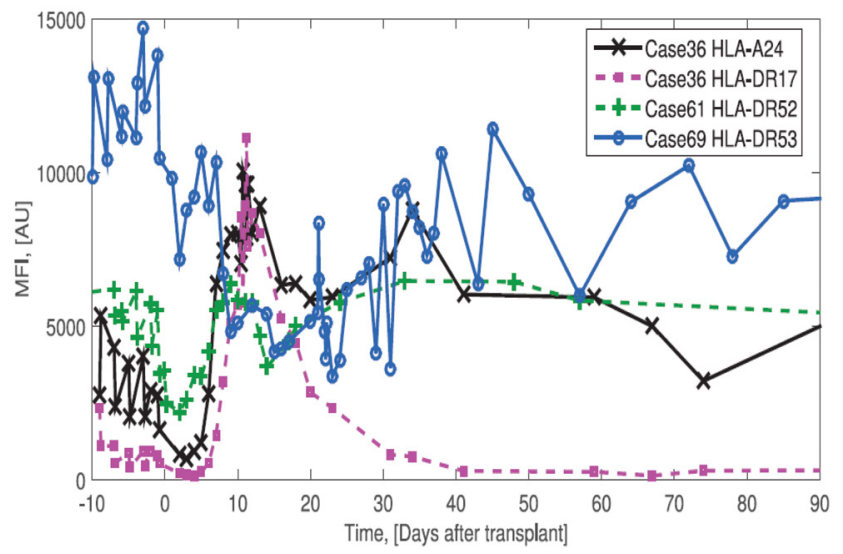

DSA-titer változása azon betegeknél, akiknél ABMR alakult ki. Látható, hogy a legtöbb betegnél a DSA-titer a 30. posztoperatív nap után is 5000 MFI körül marad

\begin{tabular}{l|l} 
4. ábra & A DSA-titer változása és az ABMR kialakulásának kockázata, a
\end{tabular} veseátültetés utáni három hónapban (Zhang Y, et al. Math Biosci $2017 ; 284: 3-11$ )

Ábramagyarázat

Case $=$ eset $;$ HLA $=$ humán leukocytaantigén; MFI = átlagoss fluoreszcenciaintenzitás; Time $=$ a veseátültetést megelőző, illetve utána eltelt idő, napokban 
a transzplantációt követő pár napban a kezdeti emelkedést titercsökkenés követi. A csökkenés eltérő mintázata alapján megállapítható, hogy a titerváltozás esetról esetre más és más; a memóriaválasz szerepe kiemelhető, a különböző alosztályok között is eltérő mintázatot kaphatunk egy adott betegnél is. A 4. ábra szemlélteti a humorális rejekciót nem mutató és a rejekciós csoport DSA-titerének mintázatát a transzplantációt követő három hónapban [45].

Mivel az ABMR kialakulását sokan a donorspecifikus antitestek megjelenéséhez kötik, érdemes tudni, hogy a DSA-k és az arteriosclerosis kialakulása közötti okozati kapcsolatot is vizsgálták veseátültetett betegeknél. Mivel a transzplantációt követően továbbra is a vezető halálokok között szerepel a cardiovascularis halálozás, ez lényeges és magát a betegtúlélést is befolyásoló tényező lehet. Az érelmeszesedést maga az immunszuppresszió is ronthatja, a kedvezőtlen metabolikus mellékhatások által. Az arteriosclerosis tradicionális rizikótényezői mellett a veseátültetettek esetén a HLA-ellenes donorspecifikus antitestek szerepe is előtérbe került az utóbbi években. Loupy és munkacsoportja a major kardiológiai események és a keringő DSA között írt le pozitív korrelációt, és agresszívebb rizikófaktor-csökkentést javasol e betegek körében, ezzel alapjaiban változtatva meg a klinikai gondolkodást a transzplantációs utógondozás során (5. ábra) [46].

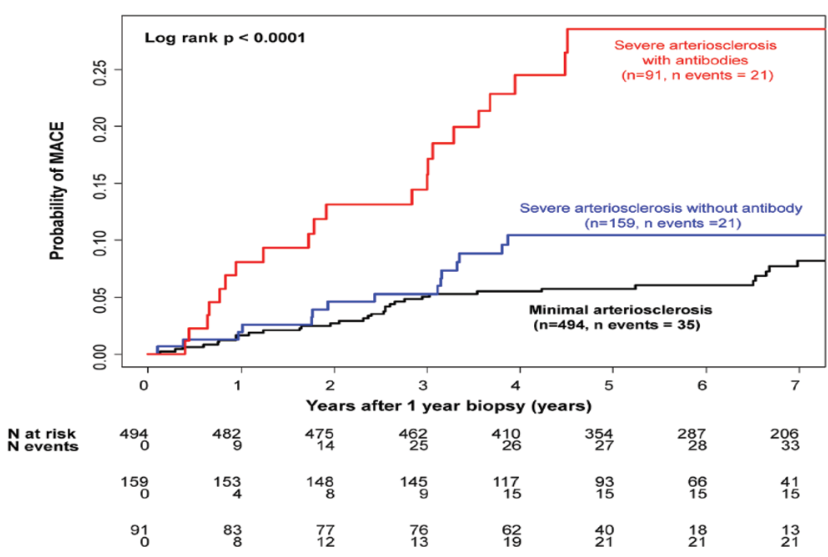

5. ábra

Súlyos kardiológiai események és a keringő DSA közötti korre láció (Loupy A, et al. Circ Res. 2015; 117: 470-482)

Az ábrán látható, hogy a súlyos kardiológiai esemény/szövőd mény/(MACE) kialakulásának esélye már l évvel a veseátültetés után szignifikánsan magasabb a DSA-pozitív csoportban (piros vonal), mint azoknál, akiknél nem alakult ki DSA (kék vonal)

Ábramagyarázat

Severe arteriosclerosis with antibodies (piros vonal) = súlyos ér elmeszesedés jelen levő antitestek mellett; Severe arteriosclerosis without antibodies (kék vonal) = súlyos érelmeszesedés antitestek jelenléte nélkül; MACE $=$ (major cardiological event) súlyos kardiológiai esemény (például infarktus); Probability = valószí núség; Minimal arteriosclerosis (fekete vonal) = kismértékű érelmeszesedés; $\mathrm{N}$ at risk = a vizsgált betegek száma; $\mathrm{N}$ events $=\mathrm{a}$ bekövetkezett esetek száma; Years after 1 year biopsy = a veseát ültetés után egy évvel végzett biopszia után eltelt idő, években

\section{Az ABMR rizikófaktorai}

Az ABMR kialakulásának alapja az alloantitestek megjelenése. Az alloantitest kialakulásának legfőbb okai a terhesség [47], az ismételt transzfúziók és a korábbi transzplantációk, melyek során a szervezet a számára idegen HLA antigénnel találkozik. A várólistán lévő betegek körülbelül 10-30\%-a tekinthető immunizáltnak, esetükben a keringő HLA-ellenes antitest 5-20\% feletti; az immunizáltság küszöbértéke eltér az egyes transzplantációs programok között. A magas panelreaktív antitesttel (PRA) rendelkező betegeket tekintik hiperimmunizáltnak. A hiperimmunizáltság küszöbe $80-85 \%$ PRA, a küszöbérték itt is változó. A hiperimmunizált felnőtt betegek aránya 10-30\% között mozog, míg gyerekeknél ez az érték 3\% körülire tehető [48]. Az alacsonyabb potenciális donorarány miatt az ő esetükben tovább tart megfelelő donort találni, így a hiperimmunizált betegek hosszabb időt töltenek a várólistán, ami magasabb ABMR-rizikót jelent.

A hiperimmunizált betegek transzplantációs esélyeinek növelésére számos stratégia létezik, úgymint a deszenzitizáció, a 'kidney pair' donáció (élődonoros vesecsereprogram) vagy az AB0-inkompatibilis (AB0i) transzplantáció. A transzplantációs programok általában a nem elfogadható, 'unacceptable' HLA antigénekkel történő transzplantáció elkerülésére törekszenek. Az Eurotransplant acceptable mismatch (AM-) programja épp fordítva múködik: az érzékeny módszerekkel definiált, a beteg történetében soha ki nem mutatott, biztosan elfogadható 'acceptable' antigénekkel történő transzplantációt részesíti előnyben. A kizárólag elfogadható HLA antigénekkel rendelkező donor esetében küldési kötelezettség van az Eurotransplant-tagállamok között [49].

A veseátültetés sajátosságából adódóan a kadáverdonor-szervet a perfúzió, a szállítás és a hidegtárolás során érő ischaemiás, majd a beültetés során keletkező reperfúziós károsodást szintén összefüggésbe hozzák az immunrendszer aktiválódásával. Állatkísérletekben modellezték, hogy a prolongált hidegischaemia aktiválja a B-sejtes immunválaszt, és elindítja a VB-sejtek érését. Ennek következtében a DSA-k és a $\mathrm{C} 4 \mathrm{~d}+-$, valamint IgG-depozitumok hamarabb megjelennek az ischaemiás graftok glomerularis bazálmembránján $[50,51]$.

$\mathrm{Az}$ ABMR kialakulásában a preformált, vagy de novo DSA-knak jelentős szerepet tulajdonítanak. Caillard és mtsai 239 veseátültetés esetén, 37 betegnél igazoltak preformált DSA-t, a veseátültetés napján vett szérumban. Ötéves megfigyelés alatt 22 betegnél a DSA-k eltüntek, 12 esetben megmaradtak. Ez utóbbi csoportra jellemző volt az 50 év alatti recipiensi életkor, a korábbi veseátültetés, a HLA II. osztálya elleni DSA-k jelenléte, egynél több DSA szimultán jelenléte, magas (átlagosan 3500 feletti) MFI-érték mellett. Ezeknél a betegeknél az ABMR incidenciája is magasabb volt [51].

Mint ebben a közleményben is tárgyaljuk, az ABMR egyik hisztopatológiai bizonyítéka - bár nem kizárólagos 
feltétele - a C4d-pozitivitás (C4d+). A Clq-kötő donorspecifikus antitesteket $(\mathrm{Clq}+\mathrm{DSA})$ az irodalom sokáig összefüggésbe hozta a veseallograft-túléléssel. Egy kanadai munkacsoport bizonyította, hogy a de novo megjelenő DSA-k titere összefügg a Clq-assay-pozitivitással, gyakrabban alakulnak ki HLA II. elleni DSA-k, továbbá $\mathrm{Clq}+-$ esetekben a szövettani leletben észlelt C4d-pozitivitás is gyakoribb. Ugyanakkor nem találták a Clq-pozitivitást önálló rizikófaktornak a graftvesztés szempontjából [52].

Moktefi és mtsai retrospektív analízisükben összehasonlították a Clq+- és Clq--eseteket, 48 bizonyítottan ABMR-pozitív biopszia (és a hozzájuk tartozó betegek adatai) alapján. Igazolták, hogy a két csoportban az allograft kumulatív túlélése nem különbözött [53].

Olasz szerzők közleménye alapján a C3d-kötő de novo DSA-k összefüggést mutatnak az ABMR kialakulásával és a graftvesztéssel is. Gyermek veseátültetetteknél összehasonlítva a 10 éves grafttúlélést, ez $40 \%$ volt a C3d+csoportban, $94 \%$ a C3d-/Clq+ csoportban, és 100\% a komplementet egyáltalán nem kötők között [54].

A University of Wisconsin munkacsoportja 146 veseátültetett beteget vizsgált, akiknél a mútét időpontjában a keresztpróba negatív eredményt adott ugyan, de preformált DSA-k jelenléte kimutatható volt. A populációt 40 év feletti és alatti csoportra osztva azt találták, hogy az idősebb recipienseknél a DSA-MFI nem emelkedett, az ABMR-incidencia 15\% volt, míg a fiatalabbaknál 30\%ban alakult ki akut antitestmediált rejekció.

\section{ABO- és HLA-inkompatibilis veseátültetések mint önálló rizikófaktor}

$\mathrm{Az}$ AB0-inkompatibilis (AB0i) veseátültetések területén érthető módon a legtöbb tapasztalat az élődonor-mútétekkel van, hiszen itt lehetőség van a mütét előtt tervezetten - és ismételten - elvégezni a deszenzitizációt. A várólistán szereplő szenzitizált (hiperszenzitizált) betegek esetében azonban nemcsak a vércsoportegyezés hiánya lehet probléma, hanem a HLA-ellenes antitestek jelenléte is. A HLA-inkompatibilis (HLAi) veseátültetések a kadávermütétekre nem jellemzőek. A CDC-keresztpróba-pozitív átültetés definíciószerúen az úgynevezett HLA-inkompatibilis átültetés, ez pedig halott donor veséjének átültetésekor hiperakut rejekcióval jár. Élődonor veseátültetés esetén van lehetőség pozitív keresztpróbát követően, tervezetten deszenzitizációt végezni, majd ismételt, már negatív CDC esetén elvégezni az élődonor veseátültetést.

Lonze és mtsai azt vizsgálták, hogy $\mathrm{AB} 0 \mathrm{i}$ veseátültetést követően a 30 napon belül észlelt ABMR milyen prognosztikai jelentőséggel bír a hosszú távú eredményekre. Retrospektív megfigyelés során 115 AB0i transzplantált beteg adatait elemezték. A betegek egyharmada egyúttal HLA-inkompatibilis is volt. A késői (hosszú távú) ABMR kialakulása szempontjából magas és alacsony kockázatú csoportot definiáltak. A vizsgált 115 beteg 26\%-ában ala- kult ki ABMR, és ennek fele 30 napon belül. Ezeknek a betegeknek (korai ABMR) ötször magasabb volt az esélyük arra, hogy késői ABMR alakuljon ki náluk. A HLAi betegeknél ez az arány még magasabb volt. A késői ABMR-arány $20,8 \%$ vs. 1,5\% volt a magas és alacsony kockázatú csoport esetén. Érdekességképpen megemlítik, hogy a mútét után mért anti-AB-titer nem korrelált az ABMR kialakulásával [55].

Más közleményekben külön is elemezték az AB0i és a HLAi (azaz pozitív keresztpróba) mellett transzplantált eseteket. Retrospektív elemzés során 69 AB0i, 27 HLAi és 10 kombinált esetet vizsgáltak. Az 5 éves kumulatív grafttúlélés $99 \%$, 69\% és $64 \%$ volt a három csoportban. $\mathrm{Az}$ egyes csoportok esetén a betegek 38\%-ában, 95\%ában és 100\%-ában diagnosztizáltak ABMR-t [56]. Érdemes megjegyezni, hogy míg az AB0i vesetranszplantáció nem szorul külön definícióra, addig a HLAi vesetranszplantáció definíciója esetén a közlemények terén jelentős eltérések mutatkoznak. Lonze és mtsai [55] közleményéból nem derül ki pontosan, hogy mi alapján definiálták a HLAi transzplantációt, de az a legvalószínúbb, hogy esetükben a kisfokú, „rossz” HLA-egyezés, illetve annak hiánya volt a kritérium; míg Couzi és mtsai [56] egyértelműen megadták, hogy HLAi-n pozitív keresztpróbát követő deszenzitizációt, majd ismételt (és immáron negatív) keresztpróbát követő transzplantációt értettek.

A HLA-ellenes antitestek szerepét többen elemezték. A kis esetszám mellett az eredmények kezdetben (2009) ellentmondásosak voltak. Sivakumaran és mtsai 10 AB0i, élődonor veseátültetésen átesett beteg adatait elemezték, akik átestek a szokásos deszenzitizáción (antiCD20-kezelés, 5 PF-kezelés + IVIG a mütét előtt). A medián AB0-antitest-titer a kezelés előtt 32 (2-128), a kezelés után 8 (1-64) és a transzplantáció után 4 (2-32) volt. Az átlagos szérumkreatinin-érték 1,45 \& 1,04 mg/ dl volt 262 nappal a veseátültetés után. 4 betegnél észleltek ABMR-t, de csak 1 graftvesztés volt emiatt (10\%) [57].

Koreai kutatók 59 AB0i veseátültetés eredményeit elemezték, kétéves utánkövetéssel. Vizsgálták a magas ( $\geq 1$ : 64 ditiotreitollal $37^{\circ} \mathrm{C}$-on, illetve $\geq 1$ : 256 antihumánglobulin-fázisban) AB0i titer mellett végzett mütétek eredményeit. A kétéves kumulatív grafttúlélés 94,9\% volt. 9 betegnél $(15,3 \%)$ tapasztaltak ABMR-t, de közülük klinikai tünetek csak 6 esetben voltak, 3 betegnél csak a szövettani eredmény jelezte az ABMR-t. Egy beteg vesztette el a beültetett vesét, hiperakut antitestmediált rejekció miatt. A kezdeti magas $\mathrm{AB} 0$-antitest-titer kockázati tényezőnek minősült. Ezeknél a betegeknél az alacsony dózisban (200 mg egyszeri adag) alkalmazott rituximab (rMAB) nem volt hatásos. A szerzők a magas antitesttiter mellett az intenzív deszenzitizációt javasolják, amely magas dózisú rMAB $\left(375 \mathrm{mg} / \mathrm{m}^{2}\right)$, IVIG és ismételt PF alkalmazását jelenti [58].

Az AB0i átültetés nemcsak vese-, hanem élődonor májátültetés esetén is jó eredményekkel jár. A deszenziti- 
zációs protokoll LRLT esetén megfelel az élődonor veseátültetést megelőzően alkalmazott eljárásnak, ugyanúgy plazmaferézis és rituximab alkalmazásán alapszik. Song és mtsai 2014-ben megjelent közleménye érdekes (és merész!) témát tárgyal, az élődonor májátültetés témakörében. Megvizsgálták a rMAB lokális (tehát a portalis vénába vagy az arteria hepaticába perfundált) alkalmazásának hatását 20 betegen, összehasonlítva 100 , hagyományosan kezelt recipienssel. Az intrahepaticus katéter 6 betegnél okozott szövődményt (30\%), és 10\%nál alakult ki diffúz intrahepaticus epeúti szúkület. Noha a beavatkozás semmilyen előnnyel nem járt az ABMRincidencia terén, az kiderült, hogy nem volt különbség az AB0-kompatibilis és -inkompatibilis élődonor májátültetések utáni betegtúlélést illetően $(88,8 \%$ vs. $94,8 \%$; $\mathrm{p}=0,11)[59]$.

A rMAB alkalmazása az ABMR kezelése vagy a deszenzitizáció során a mai napig ellentmondásos. Okada és mtsai közleményükben nagy esetszámon hasonlították össze az AB0 kompatibilis/identikus $(\mathrm{n}=412)$ és AB0inkompatibilis $(\mathrm{n}=205)$ veseátültetések eredményeit. A két fö́csoporton belül elkülönítették a rMAB-kezelésben részesült és az a nélkül átültetett betegeket. Azt a - nem meglepő tényt - igazolták, hogy az AB0-kompatibilis átültetések 5 éves kumulatív túlélése jobb volt $(97,2 \%)$, mint az inkompatibilis eseteké $(92,8 \% ; \mathrm{p}=0,003)$. Az AB0i csoportban magasabb volt a fertőzés miatt elvesztett veseallograftok aránya, azonban ABMR miatt nem történt graftvesztés. A rMAB-bal kezelt csoportban az infekciós eredetú graftvesztés még magasabb volt. Felvetik ennek alapján, hogy a rituximab alkalmazásának felülbírálata javasolt, legalább a dozírozás szintjén [60].

West-Thielke és mtsai négy AB0i élődonor veseátülttetés eredményeit elemezték. A recipiensek 9 hetes ekulizumabkezelést kaptak plazmaferézis, IVIG adása nélkül, és splenectomia sem történt. A betegek közül egyébként ketten perzisztens $\mathrm{AB} 0$ elleni antitest jelenléte ( $1: 32$ titer) mellett kerültek átültetésre. Ennek ellenére mind a négy betegnél tökéletes vesemúködést észleltek, és nem jelent meg ABMR a megfigyelési időszak végéig [61].

\section{Az ABMR kezelési stratégiája}

Az utóbbi években számos, úgynevezett antihumorális terápia jelent meg az akut ABMR kezelésére, amelyekról azt tartják, hogy hatásosak ezen rejekciós forma kezelésében [62]. Az extracorporalis kezelések, mivel gyorsan és hatékonyan képesek az alloantitestszint csökkentésére, általánosan elfogadottak mint az antihumorális terápia fontos elemei.

A hazai gyakorlatban a protokollbiopsziák 2017-ig lényegében csak egy hazai centrumban számítottak rutineljárásnak. Így a klinikai gyakorlatban a kezelőorvosok az akut kilökődés antitestmediált formáját a legtöbb esetben klinikailag kevert, sejtes és humorális rejekciónak fogták fel, és szteroidbolus-kezelést $(3-5 \times 500-250 \mathrm{mg}$ iv. Solu-Medrol), majd rezisztens esetben antithymoci- taglobulin (ATG) adását rendelték el. Ez az akut kilökődés - kismértékben mindig jelen lévő T-sejtes - celluláris részét gyógyítja, és így a beteg időt nyer. Bizonyított és tisztán humorális eredetû́ akut rejekció esetén jelenleg a plazmaferézis (PF) alkalmazása a gyakorlat. A PF-kezelést egyes központok - lehetőségeiktől függően - kiegészítik rituximab adásával. Van, ahol ennek indikációját a szövettani mintában igazolt C4d+-festődéshez kötik, és van, ahol a PF-kezelés ineffektivitása esetén alkalmazzák. A legmodernebb eljárások során már nem PF történik, hanem immunadszorpció (IA). Hazánkban is változik a kezelési eljárások lehetősége és rendje. Az Egészségügyi Szakmai Kollégium Transzplantációs Tagozati Tanácsa 2017-2018-ban előterjesztést készített a négy hazai veseátültető központ közös munkája alapján, amelyet megtárgyalt a Magyar Transzplantációs Társaság vezetősége, valamint - az immunadszorpciós komponens miatt - a Terápiás Aferezis Bizottság, végül a Transzplantációs Tagozat is. Az előterjesztés az egészségpolitikai vezetés elé került.

Az anyag lényege a következőkben foglalható össze. Az IA az akut ABMR kezelési protokolljának része, amely az IA-n kívül immunmoduláns - intravénás immunglobulin (IVIG) - és B-lymphocyta-múködést gátló készítményt, rituximabot vagy plazmasejtgátló készítményt, 26S-proteaszóma-inhibitor bortezomibot vagy ennek újabb fejlesztett változatait tartalmazza. Emellett az alap immunszuppressziós terápia mindenképpen szükséges. Amennyiben az akut rejekció egyben T-sejtes is, akkor még további iv. Solu-Medrol, erre nem kielégítô klinikai válasz esetén pedig ATG-kezelés is szükséges.

A legtöbb protokoll először 3 egymást követő napon napi egyszeri IA-kezelésből áll, ezután minden második napon, heti háromszor végzett IA-kezelés következik 2-3 hétig, azaz az összes kezelésszám 6-11 darab. A kezelés mennyiségét és a rituximab adását befolyásolja, hogy a beteget milyen súlyosságú rejekcióval kezelik, és hogy visszatérô akut humorális rejekcióról van-e szó. Más algoritmus szerint az első 3 IA-kezelés után, a másnaponta adott IA közötti napokon mindig kap rMAB-ot a beteg. A donorspecifikus antitest (DSA) rebound kivédésére, továbbá immunmodulánsként az IA-kezelések után iv. IVIG adása is szükséges lehet, a 3. IA-kezelés után és utána még 2-4 hétig heti 1 alkalommal. Az iv. rituximab dózisa $375 \mathrm{mg} / \mathrm{m}^{2}$ iv. heti 1 alkalommal, öszszesen 2-4 hétig. Eddig ugyan még nem érhetô el szisztematikus összehasonlítás az immunadszorpció és a plazmaferézis között, az azonban tény, hogy a plazmaferézis során végzett nemszelektív plazmaszeparáció nemcsak az immunglobulint távolítja el, hanem más plazmakomponenst is. Ezzel ellentétben az immunadszorpció lehetővé teszi a szelektív szeparációs eljárás révén, hogy más plazmakomponensek ne kerüljenek eltávolításra, és nincs szükség friss fagyasztott plazma vagy albumin pótlására sem. A plazmaferézissel összehasonlítva több mint kétszeres volumenú plazma kezelhetô egy kezelésben az immunadszorpció során. A legtöbb elérhető klinikai vizsgá- 
latban protein A-alapú immunadszorpció szerepel, így fontos megjegyezni, hogy az eljárás révén az IgG3 és IgM globulinok kevésbé hatásosan távolíthatók el, mint az IgG1 2,4 [63].

$\mathrm{Az}$ immunadszorpció az autoantitest által mediált (vagy okozott) betegségek terápiás lehetősége, mindenekelőtt abban az esetben, amikor e betegségeket az IgG-csoportba tartozó autoantitestek okozzák, és ellenállnak a gyógyszeres kezelésnek. Elsődlegesen az IgGosztályú antitestek eltávolítása érdekében első lépésként a plazmát elválasztják a beteg véralvadásgátlóval kezelt vérétől. Számos szeparációs eszköz létezik, úgymint sejtszeparátor vagy plazmafilter. A hagyományos plazmaferézissel ellentétben, amelynek során a szeparáció után a vérsejteket egy pótló oldattal - általában albuminnal vagy egy, a plazmához hasonló szintetikus folyadékkal összekeverik, majd ezt követően ezt az oldatot visszavezetik a szervezetbe (plazmacsere történik), az immunadszorpció esetében a plazmát átáramoltatják immunadszorbere(ke)n, és ezt követően a kezelt plazmát újra összekeverik a vérrel, és visszaadják a betegnek. Számos autoimmun betegségnél és a transzplantációs gyógyászatban is a lehető legtöbb antitestet kell eltávolítani a lehető leggyorsabban. Ilyenkor különösen hatékonyak a páros adszorberek. A kezelés során két adszorber múködik váltakozva. Az előzőekben leírt módon folyamatosan nyert, aferézishez való plazmát a páros adszorber egyikébe irányítják, és eltávolítják belőle az antitesteket és az immunkomplexeket. A plazmaáramlás és az öblítőoldatok megfigyelése és szabályozása speciális, erre a célra kifejlesztett immunadszorpciós monitorrendszerrel történik (6. ábra).

Amíg az egyik adszorbeál, azaz megköti az antitesteket, addig a másik deszorbeálódik, azaz a regenerációs fázisban van, vagyis a megkötött antitesteket eltávolítják az adszorberből, és előkészítik a következő ciklusra. Mielőtt elérnék az első adszorbernek a kötőkapacitását, a plazmát átirányítják a második adszorberbe. Ahogy az antitestek a második adszorberhez kötődnek, az első adszorberből kiöblítik az antitesteket, és előkészítik a második ciklusra. A két adszorber közti váltás szükség szerinti gyakorisággal végezhető. A kezelés során a regenerálódás olyan gyakran történik meg, amilyen gyakran szükséges. Ilyen módon tehát folyamatos immunadszorpció valósul meg. A páros adszorberek alkalmazása az immunglobulinok következetesen nagymértékű eltávolítását jelzi a kezelés teljes időtartama alatt. Itt az adszorpciós kapacitást nem korlátozza az adszorber ad-

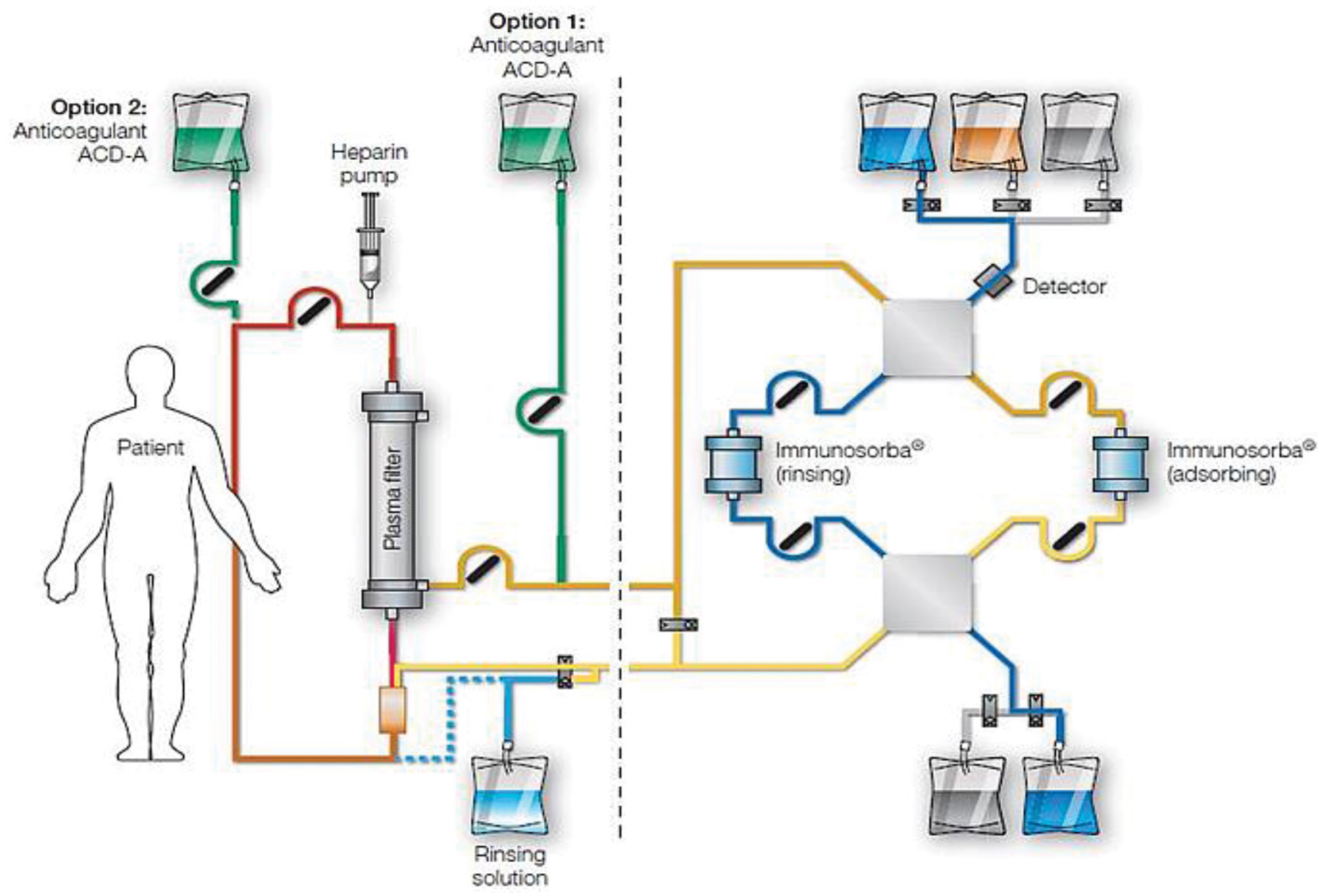

6. ábra

Immunadszorpciós eljárás sematikus ábrája

Ábramagyarázat

Anticoagulant ACD-A = savas citrát-dextróz antikoaguláns oldat; Detector = detektor; Heparin pump = heparinpumpa; Option = lehetőség; Patient =

beteg; Plasma filter $=$ plazmafilter; rinsing = öblítés; Rinsing solution $=$ öblítőoldat 
szorpciós kapacitása. A plazmatérfogat jelentősen változik az egyes betegek között. Ilyen módon az immunadszorpció dózisa speciálisan az egyes betegek plazmatérfogatához igazítható. Általános szabályként a beteg plazmatérfogatának 1,5-2,5-szeresét kezelik. Az IgGantitestek mennyisége a plazmatérfogat 1,5-szörösénél körülbelül 61\%-kal, a plazmatérfogat 2,5-szörösénél pedig körülbelül 87\%-kal csökken. Az 1990-es években, még a C4d rutin-ABMR-markerként való alkalmazása előtt, három nem kontrollált klinikai vizsgálatot végeztek, hogy megállapítsák, mennyire hatásos az immunadszorpció a veseallograft-rejekciós epizód visszafordítására. Ezekben a vizsgálatokban az immunadszorpciót mint "mentő" eljárást alkalmazták, miután más immunszuppressziós terápiás stratégiák hatástalannak bizonyultak a rejekció kezelésére. Az immunadszorpciós eljárást általában más terápiákkal együtt alkalmazták, úgymint IVIG-, ciklofoszfamid- és/vagy hagyományos antirejekciós kezelések. Annak ellenére, hogy az IA-kezelések később kezdődtek meg, 50-74\%-os rejekciós visszafordítási rátát jegyeztek fel az egyes vizsgálatok. A C4d diagnosztikai kritérium bevezetésével, amely az ABMR gyorsabb és pontosabb diagnózisát tette lehetővé, számos vizsgálat értékelte az immunadszorpció mint antirejekciós kezelés sokkal célzottabb alkalmazását. Az első esetvizsgálat során (2000) jegyezték fel egy C4d-pozitív ABMR-epizód teljes visszafordítását egy preszenzitizált női betegben [64]. Egy 2001-es, nem kontrollált klinikai vizsgálatba 1998 és 2000 között 352 transzplantált beteget vontak be. A bevont betegek közül 10 beteg felelt meg az alábbi kritériumoknak: súlyos graftdiszfunkció, C4d-lerakódás a peritubularis kapillárisokban (PTC). Mind a 10 beteg átesett immunadszorpciós kezelésen. A 10 betegből 7 beteg további celluláris rejekció jeleit is mutatta, akik magas dózisú szteroidokat kaptak, és/vagy antilymphocytaantitest-terápián is átestek. A vizsgált 10 betegből 9 esetében sikeres volt a kilökődési folyamat visszafordítása, az egyéves grafttúlélés $80 \%$-os volt. 2005-ben Min és mtsai $100 \%$-os rejekciós visszafordítási rátát publikáltak 6 fó C4d-pozitív ABMR-es beteg esetében (vizsgált betegpopuláció: 185 fó) a protein A-alapú immunadszorpciós eljárást követően [65]. A nem kontrollált esetsorozat-vizsgálatok során tapasztalt, az immunadszorpciónak az ABMR kezelésében bizonyult sikerességének hatására 2001-ben a Vienna-csoport randomizált, kontrollált, két központú klinikai vizsgálatot indított a protein A-alapú immunadszorpciós eljárás hatékonyságának bizonyítására a súlyos $\mathrm{C} 4 \mathrm{~d}$-pozitív $\mathrm{ABMR}$ kezelésében. Azon betegeket, akiknél súlyos akut graftdiszfunkció lépett fel, és C4d-lerakódás volt kimutatható a peritubularis kapillárisokban, véletlenszerúen két csoportba sorolták: (1) immunadszorpciós, (2) immunadszorpció nélküli csoport (azzal az opcióval, hogy 3 hét után lehetőség van az IA-ra mint "mentő” terápiára, amennyiben más hagyományos terápiára nem reagál a beteg). A 2001 és 2005 között transzplantált 756 betegből 10 beteg került be a klinikai vizsgálatba: 5 az immunadszorpciós és
5 az immunadszorpció nélküli vizsgálati csoportba. Az immunadszorpciós csoportban lévő összes beteg reagált az IA-kezelésre, és a rejekciós folyamatot sikerült visszafordítani. Az 5 betegből 1 fó elhalálozott, a halál oka és a sikeres rejekció visszafordítása között nem volt összefüggés (halálok: aspirációs tüdőgyulladás és szepszis). A kontrollcsoport 5 betegéból 4 fö továbbra is dialíziskezelésre szorult, 1 beteg elveszítette a graftot. Noha mind a 4 'nonresponder' beteg megkapta a „mentő" IA-terápiát, a vesefunkció egyiküknél sem javult. A 10 fő bevonása után a vizsgálatot befejezték több okból kifolyólag: (i) a kontrollcsoportban a résztvevők magas arányú nonreszponzivitása, (ii) más plazmaferézis-alapú protokollok hatásosságának bizonyítása további publikált nem kontrollált vizsgálatok alapján, (iii) a súlyos $\mathrm{ABMR}$ incidenciájának alacsony szintje. A vizsgálat idő előtti befejezése ellenére a vizsgálat megerősítette a súlyos akut C4d-pozitív ABMR nagyon kedvezőtlen prognózisát, és a protein A-alapú IA hatásosságát bizonyítja az ABMR visszafordítása tekintetében [66]. Egy berlini munkacsoport prospektív, nem randomizált vizsgálatot végzett ciklofoszfamid adásával, ABMR esetén. 13 beteget vontak be, akiknél az akut antitestmediált rejekciót biopsziával igazolták. A ciklofoszfamidot háromhetes intervallumokban, pulzusszerúen adták (15 mg/ $\mathrm{kg}$ dózisban) magas dózisú $(1,5 \mathrm{~g} / \mathrm{kg})$ IVIG mellett. Hat ciklus után tekintették a kezelést befejezettnek. Az adatokat 18 hónapos utánkövetés után elemezték. 3 beteg vesztette el a veseallograftot, a szerzők szerint noncompliance miatt (nem vitték végig a kezelést). A kezelés megkezdésekor mért kreatininérték 3 hónap után szignifikánsan csökkent, és a betegek 64\%-ában a kezdeti DSA-MFI csökkent, 36\%-uknál 500 alá. Mellékhatások miatt 9 beteget kellett hospitalizálni [67]. 2012-ben az ABMR kezelésének témájában szisztematikus irodalomáttekintést végeztek Roberts és mtsai. A publikált vizsgálatok jelentôs része nem kontrollált vizsgálat, amelyek evidenciaszintje meglehetősen alacsony. Mindösszesen 5 randomizált klinikai vizsgálatot azonosítottak, 4 plazmaferézissel, 1 pedig IAval foglalkozott. A szisztematikus irodalomáttekintés alapján a szerzők arra a következtetésre jutottak, hogy az IA alkalmazásának az a legerősebb evidenciája, hogy nincs formális bizonyíték a plazmaferézisalapú protokollok sokkal elterjedtebb alkalmazásának hatékonyságára [68]. A munkacsoport 2017-ben megismételte az áttekintést. A témával 21 vizsgálat foglalkozott, amelyek között 10 randomizált kontrollvizsgálat volt, összesen 751 beteg bevonásával. Az előző áttekintéshez képest 9 új olyan vizsgálatot azonosítottak, amely a PF-kezelés és az IVIG adását (két vizsgálat), rituximab alkalmazását (kétkét vizsgálat), Cl-inhibitor alkalmazását (két vizsgálat) vagy ekulizumab bevezetését (egy vizsgálat) vizsgálta. Megállapították, hogy a hatékonyság bizonyítottsági szintje (level of evidence) továbbra is alacsony, a legtöbb kezelési stratégia esetén. A DSA-k eltávolítását illetően valamennyi kezelési módszer kiemelkedő eredményességrôl számolt be, azonban a grafttúlélést illetően a ke- 
zelt és a kontrollcsoportok közötti eltérés nem volt szignifikáns (HR 0,76; 95\% CI 0,35-1,63; p = 0,475). A vártnál szerényebb eredmények egyik oka az ABMR diagnosztikájának felállításában, a csoportalkotásban és az utánkövetésben észlelt heterogenitás volt. Abban valamennyi kutatócsoport eredményei megegyeztek, hogy a PF vagy az IA a kezelés alapja (standard of care), és a rituximab hozzáadásának csekély hatékonyságát észlelték. A bortezomib- és a komplementinhibitor-kezelést illetően az adatok még nem elégségesek [69].

\section{Következtetések}

Az ABMR nem gyakori (3-7\%), kezdetben sokszor tünetmentes és éppen ezért veszélyes szövődmény veseátültetés után. A diagnosztikus kritériumok sokáig változtak, így a valós gyakoriságról nincs pontos adat. A diagnózis felállításában a gold standard a szövettan. Mivel a rutin (protokoll)-biopszia végzése tünet- és panaszmentes betegek esetén nehézségekbe ütközhet (a betegek együttmúködése és a szakmai centrum hozzáállása miatt), a valós arány a felfedezett esetek számánál magasabb lehet. A diagnosztikában az időzítésnek jelentős szerepe van. A második, harmadik veseátültetésen átesett fiatalabb, illetve a preformált DSA-val jelentkező betegek és azok, akik extended criteria donor-ból kapnak vesét, kockázati csoportot jelentenek. A de novo DSA megjelenése lehet az a pont, amely felhívja a figyelmet az akut ABMR kialakulásának veszélyére. Ehhez a várólistán lévő betegeket is szűrni kellene. A klinikai tünetekkel járó esetek (proteinuria, ismételt kreatininemelkedés) sokszor már nem kezelhetők, így ezeket, ha lehet, meg kell előzni. A protokollbiopszia szerepe alapvető, és felértékelödik. Ebben a betegek megfelelő tájékoztatásának és beleegyezésük elnyerésének kulcsszerepe van. A biopszia időzítése egyelőre kérdéses, lévén az egyik legnagyobb hátránya, hogy korlátlanul nem ismételhető, így negatív/kérdéses eredmény esetén rövid távú ismétlésre vagy a kezelés monitorozására sem alkalmas. A túl korán vett - negatív eredménnyel záruló - biopszia hamis biztonságérzetet kelthet, az elkésett diagnózis graftvesztéssel járhat. Felértékelődik a kiegészítő biomarkerek szerepe, amelyek alapján a leginkább a szövettani mintavétel időzítése lenne célszerü. A szövettani értékelésben az újdonságok folyamatosak. A C4d esetén elmondható, hogy hiánya nem jelenti az akut ABMR kizárását, pozitivitás esetén viszont mihamarabb és aktívan kezelni kell. A preformált és de novo DSA-k értékelése még a helyét keresi. Az MFI változása, a DSA-kinetika lehet az a pont, amely a diagnosztikában az előrejelzés szerepét elnyerheti. Ehhez további tapasztalatok szükségesek. A kezelési stratégiák alapeleme a plazmaferézis vagy az immunadszorpció. A rituximab hatékonysága nem egyértelmű, bár a debreceni gyakorlatban jók a tapasztalataink. Az új gyógyszerekkel (belatacept, bortezomib vagy ekulizumab) pedig még nincs elég tapasztalat, vagy rendkívül drágák. Saját eseteink alapján annyit tehetünk ehhez hozzá, hogy a korai diagnózis a sikeres kezelés egyik alapja. Az egyes központokban eltér a diagnosztikai és a kezelési gyakorlat. Ennek ellenére a gyógyulási arányt illetően kiemelkedően jó eredményt tudunk felmutatni.

Anyagi támogatás: A közlemény megírása, illetve a kapcsolódó kutatómunka anyagi támogatásban nem részesült.

Szerzői munkamegosztás: N. B.: Témaválasztás, az adatgyưjjtés megszervezése, ellenőrzése, az eredmények kiértékelése, a dolgozat megírása, irodalomkutatás, interpretáció, korrektúra. P. Sz. R.: Debreceni adatgyújtés, adatértékelés, részvétel a dolgozat megírásában, irodalomkutatás. Sz. A.: A szerológiai vizsgálatokkal kapcsolatos fejezet megírása, irodalomkutatás. B. L.: Patológiai elemzés, szövettani vizsgálatok, irodalom. K. N. K.: A pécsi adatok összegyújtése. I. L.: Irodalomkutatás, a biomarkerekről szóló fejezet megírása, külalaki ellenőrzés, szerkesztés. A cikk végleges változatát valamennyi szerző elolvasta és jóváhagyta.

Érdekeltségek: A szerzőknek nincsenek érdekeltségeik.

\section{Irodalom}

[1] Nemes B, Fedor R, Kanyári Z, et al. First outcomes, since being full member of Eurotransplant. A single center experience of cadaveric kidney transplantation. [Eredményeink a teljes jogú Eurotransplant-tagság óta. A Debreceni Vesetranszplantációs Központ tapasztalatai.] Orv Hetil. 2016; 157: 925-937. [Hungarian]

[2] Zádori G, Kovács DÁ, Fedor R, et al. Results of expanded-criteria donor kidneys: a single-center experience in Hungary. Transplant Proc. 2015; 47: 2189-2191.

[3] Zádori G, Tarjányi V, P Szabó R, et al. Analysis of donor scoring systems in a single Hungarian transplant centre. [Donorszelekciós kritériumok vizsgálata a debreceni veseátültetési programban.] Orv Hetil. 2016; 157: 946-955. [Hungarian]

[4] Németh N, Tóth E, Nemes B, et al. Agents targeting ischemiareperfusion injury. In: Huifang $\mathrm{C}$, Shiguang Q. (eds.) Current immunosuppressive therapy in organ transplantation. Nova Science Publishers, New York, NY, 2015; pp. 487-533.

[5] Wan SS, Ying TD, Wyburn K, et al. The treatment of antibodymediated rejection in kidney transplantation: an updated systematic review and meta-analysis. Transplantation 2018; 102: 557568.

[6] Remport A, Ivanyi B, Mathe Z, et al. Better understanding of transplant glomerulopathy secondary to chronic antibody-mediated rejection. Nephrol Dial Transplant. 2015; 30: 1825-1833.

[7] Nankivell BJ, Alexander SI. Rejection of the kidney allograft. N Eng J Med. 2010; 363: 1451-1462.

[8] van de Berg PJ, Hoevenaars EC, Yong SL, et al. Circulating lymphocyte subsets in different clinical situations after renal transplantation. Immunology 2012; 136: 198-207.

[9] Tebbe B, Wilde B, Ye Z, et al. Renal transplant recipients treated with calcineurin-inhibitors lack circulating immature transitional CD $19+\mathrm{CD} 24^{\mathrm{hi}} \mathrm{CD} 38^{\mathrm{hi}}$ regulatory B-lymphocytes. PLoS ONE 2016; 11: e0153170.

[10] Latorre I, Esteve-Sole A, Redondo D, et al. Calcineurin and mTOR inhibitors have opposing effects on regulatory $\mathrm{T}$ cells while reducing regulatory $\mathrm{B}$ cell populations in kidney transplant recipients. Transpl Immunol. 2016; 35: 1-6. 
[11] Ng YW, Singh M, Sarwal MM. Antibody-mediated rejection in pediatric kidney transplantation: pathophysiology, diagnosis, and management. Drugs 2015; 75: 455-472.

[12] Gombos P, Opelz G, Scherer S, et al. Influence of test technique on sensitization status of patients on the kidney transplant waiting list. Am J Transplant. 2013; 13: 2075-2082.

[13] Crespo M, Torio A, Mas V, et al. Clinical relevance of pretransplant anti-HLA donor-specific antibodies: does Clq-fixation matter? Transpl Immunol. 2013; 29: 28-33.

[14] Sicard A, Ducreux S, Rabeyrin M, et al. Detection of C3d-binding donor-specific anti-HLA antibodies at diagnosis of humoral rejection predicts renal graft loss. J Am Soc Nephrol 2015; 26: $457-467$.

[15] Opelz G. Non-HLA transplantation immunity revealed by lymphocytotoxic antibodies. Lancet $2005 ; 365$ : 1570-1576.

[16] Garg N, Samaniego MD, Clark D, et al. Defining the phenotype of antibody-mediated rejection in kidney transplantation: advances in diagnosis of antibody injury. Transplant Rev (Orlando). 2017; 31: 257-267

[17] Stegall MD, Raghavaiah S, Gloor JM. The (re)emergence of B cells in organ transplantation. Curr Opin Organ Transplant. 2010; 15: 451-455.

[18] Lan JH, Tinckam K. Clinical utility of complement dependent assays in kidney transplantation. Transplantation 2018; 102(1S): S14-S22.

[19] Karahan GE, Claas FH, Heidt S. B cell immunity in solid organ transplantation. Front Immunol. 2017; 7: 686.

[20] Courant M, Visentin J, Linares G, et al. The disappointing contribution of anti-human leukocyte antigen donor-specific antibodies characteristics for predicting allograft loss. Nephrol Dial Transplant. 2018; 33: 1853-1863.

[21] De Serres SA, Mfarrej BG, Magee CN. Immune profile of pediatric renal transplant recipients following alemtuzumab induction. J Am Soc Nephrol. 2012; 23: 174-182.

[22] Todeschini M, Cortinovis $M$, Perico N. In kidney transplant patients, alemtuzumab but not basiliximab/low-dose rabbit antithymocyte globulin induces B cell depletion and regeneration, which associates with a high incidence of de novo donor-specific anti-HLA antibody development. J Immunol. 2013; 191: 28182828.

[23] Sigdel TK, Vitalone MJ, Tran TQ, et al. A rapid noninvasive assay for the detection of renal transplant injury. Transplantation 2013; 96: 97-101.

[24] Kohei J, Ishida H, Tanabe K, et al. Neutrophil gelatinase-associated lipocalin is a sensitive biomarker for the early diagnosis of acute rejection after living-donor kidney transplantation. Int Urol Nephrol. 2013; 45: 1159-1167.

[25] Heng B, Li Y, Shi L, et al. A meta-analysis of the significance of granzyme $\mathrm{B}$ and perforin in noninvasive diagnosis of acute rejection after kidney transplantation. Transplantation 2015; 99: 1477-1486.

[26] Wulff H, Knaus HG, Pennington M, et al. $\mathrm{K}^{+}$channel expression during $\mathrm{B}$ cell differentiation: implications for immunomodulation and autoimmunity. J Immunol. 2004; 173: 776-786.

[27] Han S, Yi H, Yin SJ, et al. Structural basis of a potent peptide inhibitor designed for Kvl.3 channel, a therapeutic target of autoimmune disease. J Biol Chem. 2008; 283: 19058-19065.

[28] Bezerra EL, Vilar MJ, da Trindade Neto PB, et al. Double-blind, randomized, controlled clinical trial of clofazimine compared with chloroquine in patients with systemic lupus erythematosus. Arthritis Rheum. 2005; 52: 3073-3078.

[29] Chuaprapaisilp T, Piamphongsant T. Treatment of pustular psoriasis with clofazimine. Br J Dermatol. 1978; 99: 303-305.

[30] Selby W, Pavli P, Crotty B, et al. Two-year combination antibiotic therapy with clarithromycin, rifabutin, and clofazimine for Crohn's disease. Gastroenterology 2007; 132: 2313-2319.

[31] Roedder S, Sigdel T, Salomonis N, et al. The kSORT assay to detect renal transplant patients at high risk for acute rejection: results of the multicenter AART study. PLOS Med. 2014; 11: e1001759. Correction: https://journals.plos.org/plosmedicine/article?id=10.1371/journal.pmed. 1001790

[32] van de Vrie M, Deegens JK, Eikmans M, et al. Urinary microRNA as biomarker in renal transplantation. Am J Transplant. 2017; 17: 1160-1166.

[33] Gelley F, Zadori G, Nemes B, et al. MicroRNA profile before and after antiviral therapy in liver transplant recipients for hepatitis C virus cirrhosis. J Gastroenterol Hepatol. 2014; 29: 121127.

[34] Zununi Vahed S, Poursadegh Zonouzi A, Ghanbarian H, et al. Upregulated expression of circulating microRNAs in kidney transplant recipients with interstitial fibrosis and tubular atrophy. Iran J Kidney Dis. 2017; 11: 309-318.

[35] Zununi Vahed S, Poursadegh Zonouzi A, Mahmoodpoor F, et al. Circulating miR-150, miR-192, miR-200b, and miR-423-3p as non-invasive biomarkers of chronic allograft dysfunction. Arch Med Res. 2017; 48: 96-104

[36] Millán O, Budde K, Sommerer C, et al. Urinary miR-155-5p and CXCL10 as prognostic and predictive biomarkers of rejection, graft outcome and treatment response in kidney transplantation. Br J Clin Pharmacol. 2017; 83: 2636-2650.

[37] Iwasaki K, Yamamoto T, Inanaga $Y$, et al. MiR-142-5p and miR486-5p as biomarkers for early detection of chronic antibodymediated rejection in kidney transplantation. Biomarkers 2017; 22: $45-54$.

[38] Hidalgo LG, Sis B, Sellares J, et al. NK cell transcripts and NK cells in kidney biopsies from patients with donor-specific antibodies: evidence for NK cell involvement in antibody-mediated rejection. Am J Transplant. 2010; 10: 1812-1822.

[39] Loupy A, Lefaucheur C, Vernerey D, et al. Molecular microscope strategy to improve risk stratification in early antibody-mediated kidney allograft rejection. J Am Soc Nephrol. 2014; 25: 22672277.

[40] Ivanyi B. Transplant capillaropathy and transplant glomerulopathy: ultrastructural markers of chronic renal allograft rejection. Nephrol Dial Transplant. 2003; 18: 655-660.

[41] Haas M, Loupy A, Lefaucheur C, et al. The Banff 2017 Kidney Meeting Report: Revised diagnostic criteria for chronic active T cell-mediated rejection, antibody-mediated rejection, and prospects for integrative endpoints for next-generation clinical trials. Am J Transplant. 2018; 18: 293-307.

[42] Dobi D, Bodó Z, Kemény É, et al. Peritubular capillary basement membrane multilayering in early and advanced transplant glomerulopathy: quantitative parameters and diagnostic aspects. Virchows Arch. 2016; 469: 563-573.

[43] Lipták P, Kemény E, Morvay Z, et al. Peritubular capillary damage in acute humoral rejection: an ultrastructural study on human renal allografts. Am J Transplant. 2005; 5: 2870-2876.

[44] Mohan S, Palanisamy A, Tsapepas D, et al. Donor-specific antibodies adversely affect kidney allograft outcomes. J Am Soc Nephrol. 2012; 23: 2061-2071.

[45] Zhang Y, Briggs D, Lowe D, et al. A new data-driven model for post-transplant antibody dynamics in high risk kidney transplantation. Math Biosci. 2017; 284: 3-11.

[46] Loupy A, Vernerey D, Viglietti D, et al. Determinants and outcomes of accelerated arteriosclerosis: major impact of circulating antibodies. Circ Res. 2015; 117: 470-482.

[47] Sagasaki M, Nakada Y, Yamamoto I, et al. Antibody-mediated rejection due to anti-HLA-DQ antibody after pregnancy and delivery in a female kidney transplant recipient. Nephrology (Carlton) 2018; 23(Suppl 2): 81-84.

[48] Shapiro R, Sarwal MM. Pediatric kidney transplantation. Pediatr Clin North Am. 2010; 57: 393-400.

[49] Heidt S, Haasnoot GW, van Rood JJ, et al. Kidney allocation based on proven acceptable antigens results in superior graft survival in highly sensitized patients. Kidney Int. 2018; 93: 491500 . 
[50] Solini S, Aiello S, Cassis P, et al. Prolonged cold ischemia accelerates cellular and humoral chronic rejection in a rat model of kidney allotransplantation. Transpl Int. 2012; 25: 347-356.

[51] Caillard S, Becmeur C, Gautier-Vargas G, et al. Pre-existing donor-specific antibodies are detrimental to kidney allograft only when persistent after transplantation. Transpl Int. 2017; 30: $29-40$.

[52] Wiebe C, Gareau AJ, Pochinco D, et al. Evaluation of Clq status and titer of de novo donor-specific antibodies as predictors of allograft survival. Am J Transplant. 2017; 17: 703-711.

[53] Moktefi A, Parisot J, Desvaux D, et al. Clq binding is not an independent risk factor for kidney allograft loss after an acute antibody-mediated rejection episode: a retrospective cohort study. Transpl Int. 2017; 30: 277-287.

[54] Comoli P, Cioni M, Tagliamacco A, et al. Acquisition of C3dbinding activity by de novo donor-specific HLA antibodies correlates with graft loss in nonsensitized pediatric kidney recipients. Am J Transplant. 2016; 16: 2106-2116.

[55] Lonze BE, Bae S, Kraus ES, et al. Outcomes and risk stratification for late antibody-mediated rejection in recipients of $\mathrm{AB} 0$ incompatible kidney transplants: a retrospective study. Transpl Int. 2017; 30: 874-883.

[56] Couzi L, Manook M, Perera R, et al. Difference in outcomes after antibody-mediated rejection between $\mathrm{AB} 0$-incompatible and positive cross-match transplantations. Transpl Int. 2015;28: $1205-1215$

[57] Sivakumaran P, Vo AA, Villicana R, et al. Therapeutic plasma exchange for desensitization prior to transplantation in AB0-incompatible renal allografts. J Clin Apher. 2009; 24: 155-160.

[58] Lee KW, Park JB, Oh DK, et al. Short-term outcomes of AB0incompatible living donor kidney transplantation with uniform protocol: significance of baseline anti-AB0 titer. Transplant Proc. 2016; 48: 820-826.

[59] Song GW, Lee SG, Hwang S, et al. Section 15. A desensitizing protocol without local graft infusion therapy and splenectomy is a safe and effective method in $\mathrm{AB} 0$-incompatible adult LDLT. Transplantation 2014; 97(Suppl 8): S59-S66.

[60] Okada M, Watarai Y, Iwasaki K, et al. Favorable results in AB0incompatible renal transplantation without $\mathrm{B}$ cell-targeted thera- py: advantages and disadvantages of rituximab pretreatment. Clin Transplant. 2017; 31: e13071.

[61] West-Thielke P, Progar K, Campara M, et al. Eculizumab for prevention of antibody-mediated rejection in blood group-incompatible renal transplantation. Transplant Proc. 2018; 50: 66-69.

[62] Bartel G, Schwaiger E, Böhmig GA, et al. Prevention and treatment of alloantibody-mediated kidney transplant rejection. Transpl Int. 2011; 24: 1142-1155.

[63] Habicht A, Regele H, Exner M, et al. A case of severe C4d-positive kidney allograft dysfunction in the absence of histomorphologic features of rejection. Wien Klin Wochenschr. 2002; 114: 945-948.

[64] Böhmig GA, Regele H, Säemann MD, et al. Role of humoral immune reactions as target for antirejection therapy in recipients of a spousal-donor kidney graft. Am J Kidney Dis. 2000; 35: 667-673.

[65] Min L, Shuming J, Zheng T, et al. Novel rescue therapy for C4dpositive acute humoral renal allograft rejection. Clin Transplant. 2005; 19: 51-55.

[66] Böhmig GA, Wahrmann M, Regele $\mathrm{H}$, et al. Immunoadsorption in severe C4d-positive acute kidney allograft rejection: a randomized controlled trial. Am J Transplant. 2007; 7: 117-121.

[67] Waiser J, Duerr M, Budde K, et al. Treatment of acute antibodymediated renal allograft rejection with cyclophosphamide. Transplantation 2017; 101: 2545-2552.

[68] Roberts DM, Jiang SH, Chadban SJ, et al. The treatment of acute antibody-mediated rejection in kidney transplant recipients - a systematic review. Transplantation 2012; 94: 775-783.

[69] Wan SS, Ying TD, Wyburn K, et al. The treatment of antibodymediated rejection in kidney transplantation: an updated systematic review and meta-analysis. Transplantation 2018; 102: 557568.

(Nemes Balázs dr., Debrecen, Móricz Zs. krt 22., 4032 e-mail: abnemes@hotmail.com)

\title{
Felhívás előfizetésre
}

\author{
Legyen Olvasónk a következő évben is! \\ Fizessen elö az Orvosi Hetilap 2019-es évfolyamára! \\ Egy füzet ára: $1150 \mathrm{Ft}$. \\ Éves előfizetési díj: $49900 \mathrm{Ft}$, nyugdijasoknak: $39990 \mathrm{Ft}$. \\ Az online változat éves előfizetési díja: $29990 \mathrm{Ft}$.
}

A cikk a Creative Commons Attribution-NonCommercial 4.0 International License (https://creativecommons.org/licenses/by-nc/4.0) feltételei szerint publikált Open Access közlemény, melynek szellemében a cikk nem kereskedelmi célból bármilyen médiumban szabadon felhasználható, megosztható és újraközölhető, feltéve, hogy az eredeti szerző és a közlés helye, illetve a CC License linkje és az esetlegesen végrehajtott módosítások feltüntetésre kerülnek. 